\title{
Structural, petrological and chemical analysis of syn-kinematic migmatites: insights from the Western Gneiss Region, Norway.
}

\author{
A.C. GANZHORN, ${ }^{1,2,3,4,5}$ L. LABROUSSE, ${ }^{1,2}$ G. PROUTEAU, ${ }^{3,4,5}$ C. LEROY, ${ }^{6,7}$ J.C. \\ VRIJMOED ${ }^{8}$ T.B. ANDERSEN, ${ }^{9}$ AND L. ARBARET ${ }^{3,4,5}$ \\ ${ }^{1}$ Institut des Sciences de la Terre de Paris, University of Paris 06, UMR 7193, F-75005, \\ Paris, France (anne-celine.ganzhorn@upmc.fr)
}

(2) CNRS, UMR 7193, F-75005, Paris, France.

(3) Institut des Sciences de la Terre d'Orléans, University of Orléans, UMR 7327, F-45071, Orléans, France.

(4) CNRS/INSU, UMR 7327, F-45071, Orléans, France.

(5) BRGM, UMR 7327, F-45071, Orléans, France.

(6) Institut de Minéralogie de Physique et Matériaux Condensés, University of Paris 06, UMR 7590, F-75005, Paris, France.

(7) CNRS, UMR 7590, F-75005, Paris, France.

(8) Institut des Sciences de la Terre, University of Lausanne, UNIL-Mouline, Bâtiment Géopolis, CH-1015, Lausanne, Switzerland.

(9) Center of Earth Evolution and Dynamics, University of Oslo, P.O. Box 1048 Blindern, N0316, Oslo, Norway.

Running title: Chemical, petrological and structural analysis of syn-kinematic migmatite

\begin{abstract}
Evidence of melting is presented from the Western Gneiss Region (WGR) in the core of the Caledonian orogen, Western Norway and the dynamic significance of melting for the evolution of orogens is evaluated. Multiphase inclusions in garnets that comprise plagioclase, potassic feldspar and biotite are interpreted to be formed from melt trapped during garnet growth in the eclogite facies. The multiphase inclusions are associated with rocks that preserve macroscopic evidence of melting, such as segregations in mafic rocks, leucosomes and pegmatites hosted in mafic rocks and in gneisses. Based on field studies, these lithologies are found in three structural positions: (1) as zoned segregations found in high-pressure (HP) (ultra) mafic bodies, (2) as leucosomes along amphibolite facies foliation and in a variety of discordant structures in gneiss, and (3) as undeformed pegmatites cutting the main Caledonian structures. Segregations post-date the eclogite facies foliation and predate the amphibolite facies deformation, whereas leucosomes are contemporaneous with the amphibolite facies deformation and undeformed pegmatites are post-kinematic and were formed at the end of the deformation history. Geochemistry of the segregations, leucosomes and pegmatites in the WGR defines two trends, which correlate with the mafic or felsic nature of the host rocks. The first trend with Ca-poor compositions represents leucosome and pegmatite hosted in felsic gneiss, whereas the second group with K-poor compositions corresponds to segregation hosted in (ultra) mafic rocks. These trends suggest partial melting of two separate sources: the felsic gneisses and also the included mafic eclogites. The REE patterns of the samples allow distinction between melt compositions, fractionated liquids and cumulates. Melting began at high pressure and affected most lithologies in the WGR before or during their retrogression in the amphibolite facies. During this stage, the presence of melt may have acted as a weakening mechanism that enabled decoupling of the exhuming crust
\end{abstract}


around the peak pressure conditions triggering exhumation of the upward-buoyant crust. Partial melting of both felsic and mafic sources at temperatures below $800^{\circ} \mathrm{C}$ implies the presence of an $\mathrm{H}_{2} \mathrm{O}$-rich fluid phase at great depth to facilitate $\mathrm{H}_{2} \mathrm{O}$-present partial melting.

Keywords: Migmatite, leucosome, partial melting, Western Gneiss Region, (U)HP.

\section{INTRODUCTION}

Partial melting of the continental crust is considered as a weakening process prone to induce lower-crustal macroscopic ductile flow in orogenic belts (Teyssier \& Whitney, 2002; Vanderhaeghe, 2009) and play an important role in the exhumation of ultra-high pressure (UHP) rocks (Sizova et al., 2012). Presence of melt indeed affects both thermal (Bittner \& Schmelling, 1995) and rheological (Rosenberg \& Handy, 2005) behaviour of the crust during orogeny, probably from the very first increments of melt generated. Thus, the initiation and duration of any melting event needs to be well constrained to determine the rheological impact of partial melting at the scale of an orogeny.

One way to try to constrain the partial melting interval is to perform isotopic dating of newly formed accessory minerals included in leucosomes (Hermann et al., 2001; Tucker et al., 2004; Kohn et al., 2005; Kylander-Clark et al., 2008, Gordon et al., 2013). However, in most cases, such an approach provides only the timing of crystallization in migmatites and not the initiation of partial melting. In-situ analysis of zircon and monazite, both minerals that may dissolve and grow by interaction with melts, may allow more precise dating of growth rims in those minerals (Hermann et al., 2001; Foster et al., 2004). However, interpretation of ages is limited by the difficult correlation of accessory mineral growth with $P-T$ history deduced from metamorphic paragenesis (Gibson et al., 2004). Moreover, partial melting at metamorphic peak and partial melting during early decompression may be indistinguishable within analytical uncertainty (Hermann et al., 2001).

Another way to assess the initiation of partial melting is to relate the first melt increment with $P-T$ conditions. Good evidence of melt presence at or soon after the peak pressure at UHP metamorphic conditions, i.e. in the stability field of coesite, is provided by multi-phase solid inclusions that are interpreted to have crystallized from a supercritical fluid or a melt phase (Stöckert et al., 2001; Korsakov \& Hermann, 2006; Lang \& Gilotti, 2007, Gao et al., 2013). The conditions of entrapment of these inclusions may be inferred from their mineral assemblage (e.g. existence of micro-diamand, Stöckert et al., 2001; Korsakov \& Hermann, 2006), from the multi-phase solid inclusions host peak mineral assemblage (Lang \& Gilotti, 2007), or from their rare earth elements (REE) content (Gao et al., 2013).

The Western Gneiss Region (WGR) in the Norwegian Caledonides presents excellent exposure of migmatites associated with UHP eclogites and amphibolite facies gneisses. $P-T$ paths and deformation history are well constrained (e.g. Cuthbert et al., 2000; Engvik \& Andersen 2000; Labrousse et al., 2004; Hacker et al., 2010). Moreover, pressure peaks recorded by UHP eclogites trend between the water-saturated granitic solidus and the water under-saturated metapelite solidus in $P-T$ space, suggesting that partial melting may have started at UHP conditions (Labrousse et al., 2011). These observations lead us to choose the WGR as a case study to investigate the relationships between partial melting, (U)HP metamorphism and subsequent retrogression.

The aim of this study is to use relationships between metamorphism, deformation and partial melting to determine the $P-T$ range where melt was present to evaluate the possible effect of anatexis on the exhumation of UHP rocks and particularly on the initiation of exhumation. We describe new occurrences of multiphase inclusions interpreted to relate to 
UHP partial melting. Furthermore, the petrogenesis of associated segregations in mafic rocks, leucosomes in gneisses, and pegmatites and is related to their structural position and relative chronology with reference to eclogite bodies and their retrogression. The compositions of melt-derived rocks sampled in the field are compared to the compositions of experimentally produced melts in metapelitic and mafic systems at various pressures, temperatures and water contents to determine the possible melt sources in the WGR. Finally, we discuss the significance of this study in terms of major and trace element compositions and partial melting conditions.

\section{GEOLOGICAL SETTING}

The WGR dominantly consists of Middle Proterozoic Baltican basement (e.g. Austrheim et al., 2003) that was buried to HP-UHP conditions during westward-directed subduction that formed the Scandinavian Caledonides. Subduction was followed by the Scandian continental collision between Baltica and Laurentia after the Iapetus Ocean closed in the Middle Silurian to Early Devonian (e.g. Andersen et al. 1991, Corfu et al. 2006). The collision stage lasted approximately from 430 to $400 \mathrm{Ma}$ (e.g. Hacker et al. 2010). The mountain belt subsequently underwent extension, partly contemporaneous with the collision as indicated by formation of lower Devonian supra-detachment basins in the uppermost preserved levels (Andersen, 1998). Extension, however, continued into the Middle Devonian (Andersen \& Jamtveit, 1990; Andersen, 1998; Roberts, 2003; Fossen, 2010) and is responsible for exhumation and amphibolite facies structures in the WGR.

As a result, the WGR appears as a basement core within the Norwegian Caledonides, structurally at the base of the nappe stack (Roberts \& Gee, 1985) and bounded by large extensional shear zones: the Nordfjord-Sogn Detachment Zone (NSDZ) to the West, the Bergen Arc Shear Zone (BASZ) to the South (not shown in Fig. 1), the Jotunheimen Detachment Zone to the East and the Møre-Trøndelag Shear Zone (MTSZ) to the North (Fig. 1).

The main lithology in the WGR corresponds to gneisses classified as augen-gneisses and associated massive gneisses, banded gneisses and mangerites (Bryhni, 1966). Also included and generally described as "gneiss" are quartz-micaschist, feldspathic quartzite, granitic rocks and pelitic gneisses with abundant mica that alternate at a decameter scale. The gneisses are quartz and plagioclase rich with minor K-feldspar and commonly two-micas (Bryhni, 1966).

In the WGR, the gneiss contains numerous lenses of mafic eclogite facies rocks either scattered within the gneiss host or define trails in the stretching direction, several isolated 20 2000 meters long bodies of ultramafic rocks (dunite and peridotite), and massive (meta-) anorthosites and granulite facies igneous rocks (Bryhni, 1966). Thus, the continental crust represented by the WGR is highly heterogenous both in terms of lithology and metamorphic facies as UHP eclogites are associated with HP eclogites and granulite facies rocks, which did not re-equilibrated during Caledonian burial (e.g. Bryhni, 1966; Krabbendam et al., 2000; Austrheim et al., 2003).

Eclogite facies rocks contain garnet, omphacite, orthopyroxene, phengite, kyanite, rutile, quartz and, when retrogressed, minor amphibole, zoisite and biotite. Throughout the WGR, eclogite facies fabrics are marked by a range of foliation orientations, trending mostly E-W in the Nordfjord and Nordøyane areas, that are associated with gently plunging lineations (review in Hacker et al., 2010). Identification of coesite (Smith, 1984; Wain, 1997; Cuthbert et al., 2000) and microdiamond (Dobrzhinetskaya et al., 1995; van Roermund et al., 2002; Vrijmoed et al., 2008) in eclogite bodies or in the surrounding gneisses led to the 
identification of several UHP domains in the HP region of the WGR (Fig. 1, Root et al., 2005; Hacker et al., 2010). Pressure and temperature estimates deduced from eclogite facies rocks from the WGR show an increase in peak conditions towards the northwest (from $600^{\circ} \mathrm{C}, 2$ $\mathrm{GPa}$ in the south up to $850^{\circ} \mathrm{C}, 4 \mathrm{GPa}$ in the Moldefjord area; compiled in Labrousse et al., 2011).

Numerous titanite ages, relevant for dating the amphibolite overprint in the gneisses (closure temperature of titanite is considered to be $>650^{\circ} \mathrm{C}$ and up to $750^{\circ} \mathrm{C}$ at UHP; Kylander-Clark et al., 2008; Spencer et al., 2013), define a concordant-discordant titanite isograd (Fig. 1). The isochrons defined by titanite ages in the HP and UHP domains do not correlate with Caledonian structures (Labrousse et al., 2011; Spencer et al., 2013). The Caledonian structures, defined by amphibolite facies fabrics comprising K-feldspar, white mica, hornblende, biotite, plagioclase and quartz mineral assemblages in the gneisses, are characterized by $\mathrm{E}-\mathrm{W}$ striking foliations associated with $\mathrm{E}-\mathrm{W}$ plunging lineations and fold axes (review in Hacker et al., 2010).

Although migmatites and granitic leucosomes have been described throughout the WGR (e.g. Bryhni, 1966), distinction between pre-Caledonian and Caledonian leucosomes, as well as correlation of the post-eclogite metamorphism has not been carried out systematically. The distribution of migmatites shows that a broad domain of Caledonian partial melting encompasses three UHP domains along the coast (Labrousse et al., 2002; Tucker et al., 2004; Hacker et al., 2010; Butler et al., 2013, Gordon et al., 2013). The frequency and volume of leucosome within the migmatite complexes increase toward northwest (Hacker et al., 2010).

\section{DIVERSITY OF ROCKS REVEALING MELTING IN THE WGR}

\section{Host rocks: gneiss, gabbro and amphibolite}

Samples analysed in this study were collected from two distinct types of host: felsic gneisses and mafic eclogite facies rocks. The felsic gneisses have a strong foliation marked by amphibolite facies minerals, which was acquired during exhumation. They are deformed along ductile structures, such as folds or shear zones.

Mafic eclogite facies rocks occur as metric lenses dispersed in the gneisses (e.g. eclogite in Svartberget) or form metric to kilometric bodies (e.g. Flemsøy gabbro).

Commonly, they show retrogression to amphibolite facies mineral assemblages at their margins in contact with gneiss. In this study, two localities with mafic hosts are discussed in terms of the microtextures and chemistry: the Flemsøy gabbro and the Bud amphibolite.

The Flemsøy gabbro crops out within the northernmost UHP domain (Fig. 1) and was intensively studied as an example of progressive transformation into eclogite by Mørk (1985). It forms a $500 \mathrm{~m}$ long body embedded in gneiss. Smaller eclogite facies lenses are present within the gneiss around the gabbro (Mørk, 1985). The Flemsøy gabbro is deformed along millimetre thick eclogite facies shear bands (Krogh et al., 2011) and exhibits an eclogite facies foliation. Sample NO11-31 comes from Flemsøy gabbro.

The Bud amphibolite forms a continuous kilometres-long outcrop in migmatized gneisses along the northernmost coast of the study area (Fig. 1). Amphibolite facies rocks correspond to layers that have been intensively elongated and now form numerous boudins. Sample NO11-09 comes from one of the amphibolite facies boudins in the Bud amphibolite.

\section{Segregations in mafic-hosts, leucosomes in gneisses and pegmatites}


In the following parts, sample names are followed by two subscripts as in Table 1: the first subscript refers to the structural group ( $\mathrm{s}=$ segregation in mafic host, $1=$ leucosome, $\mathrm{p}=$ pegmatite) and the second subscript refers to the nature of the host ( $\mathrm{m}=$ mafic, $\mathrm{g}=$ gneiss).

Out of approximately one hundred samples collected from the WGR between Nordfjord and Hustad, twenty-one segregations in mafic hosts, leucosomes and pegmatites were selected for a coupled structural, petrological and geochemical study (sample location in Fig. 1). These samples are of certain Caledonian age, i.e. related to eclogite facies structures or to retrogression after the eclogite facies metamorphism. The samples do not organize in an interconnected network at a regional scale, but form discrete isolated bodies. In the field, the segregations, leucosomes and pegmatites show different structural relationships with amphibolite facies foliation in the gneisses and eclogite facies structures in the mafic rocks. Thus, it is possible to classify them into three structural populations, as follows.

(1) The first population is found as segregations trapped inside mafic bodies, without any connection to the surrounding gneisses (hereafter "segregations"; FLEM111 $1_{\text {s-m }}$, FLEM112 ${ }_{\text {s-m }}$ ). The Flemsøy locality (Fig. 1), detailed here, which contains multiple examples of segregations, is a representative example of segregations observed in (ultra)mafic rocks at other localities (Otrøy and Svartberget, for instance). In this particular outcrop, an eclogite facies olivine-bearing gabbro occurs in the gneisses (see description in Mørk, 1985). Clear relations between eclogite facies deformation and different vein types are visible. The segregations show zonation in modal and bulk-rock composition between the margin and core (Fig. 2a), which has previously been described by a variety of terms ("mafic dykes" Mørk, 1985; "felsic gabbro dykes" Krogh et al., 2011). These segregations are composed of milkygreen amphibole-clinopyroxene symplectite-bearing borders (FLEM-11 $1_{\mathrm{s}-\mathrm{m}}$ ) with a discontinuous light pink quartz and feldspar-rich pegmatite core (FLEM112 $2_{\mathrm{s}-\mathrm{m}}$, Fig. 2a). They strike N030-040, and are oblique to the E-W trending eclogite facies foliation in the gabbro marked by the preferred orientation of clinopyroxene and phlogopite. Segregation edges have sinuous shapes (Fig. 2a) and no amphibolite facies retrogressive halo can be observed in the host metagabbro. A very thin $(\sim 1 \mathrm{~mm})$ layer of phlogopite is present between the symplectitebearing borders and the metagabbro. The Flemsøy gabbro also contains undeformed pegmatites (Fig. 2b), however, they are not structurally connected with the segregations. Late intrusion of undeformed pegmatites within the gabbro leads to retrogression of the eclogite facies assemblage to an amphibolite facies assemblage along both sides of the undeformed pegmatites (Fig. 2b).

(2) The second population comprises leucosomes that commonly occur parallel to the amphibolite facies foliation in the gneisses and which are present in most of the WGR. The leucosome may have been deformed together with the gneisses (Fig. 3a) or it may be located in shear zones, along axial planes of folds, or within necks between boudins (Fig. 3b, c, \& d). Leucosome also intrudes the eclogite lenses, where it promote retrogression to an amphibolite facies assemblage of hornblende + plagioclase \pm garnet. Edges of leucosomes are sinuous. Leucosome also forms patches within the gneisses (Fig. 3e) and mafic rocks (Fig. 4a). In each eclogite lens, patchy leucosome veins are oriented in a single direction (N090 in Fig. 4a), generally sub-perpendicular to the long axis of the lens (N015 in Fig. 4a).

In the Bud amphibolite two distinct types of leucosome are present (Fig. 5). NO10-51 $\mathrm{m}$ was sampled from the strain shadow of an amphibolite boudin, whereas NO11-12 1 -m represents white patchy pockets associated with amphibolite boudins (Fig. 5).

(3) The third population corresponds to undeformed quartzo-feldspathic pegmatites, which vary in thickness from a few centimetres to one metre and cut across the amphibolite facies foliation in the gneisses (Fig. 6). The undeformed pegmatites show limited stretching or shortening after intrusion and present sharp planar margins (Fig. 6a). In Sjøholt, the 
undeformed pegmatites are connected and may represent a local vein network (Fig. 6b). Leucosomes in the gneissic foliation are cut in places by undeformed pegmatites, as seen in Gurskøy and Otrøy (Fig. 6c and d). In that case, the distinction between both structural populations is established from outcrop to thin section scales (Fig. 7a). In eclogite facies rocks, undeformed pegmatites are also responsible for amphibolite facies retrogression. The orientation of undeformed pegmatites is systematically perpendicular to the local amphibolite facies stretching lineation (the angle between undeformed pegmatites and stretching lineation in Otrøy is $70-80^{\circ}$, at Hustad is $100^{\circ}$, in the Bud amphibolite is $90^{\circ}$, and at Tangen is $80^{\circ}$ ).

\section{Relative chronology of segregations, leucosomes and pegmatites with regard to eclogite and amphibolite facies fabrics}

Using field observations it is possible to establish a relative chronology between the three structural populations (Fig. 8). This chronology is not only valid at the outcrop scale but also is systematically observed over the whole WGR.

Segregations belonging to population 1 (Fig. 8) are found only within HP (ultra)mafic bodies. They locally cut across the eclogite facies foliation in their host (Fig. 2a), and are themselves affected by discrete eclogite facies shear zones (Terry, 2000; Krogh et al., 2011). Population 1 is therefore interpreted to be due to local-scale segregation inside their mafic host under eclogite facies conditions.

Leucosomes belonging to population 2 (Fig. 8) are located in the gneissic foliation and are deformed with the gneisses, i.e. they are either pre- or syn-kinematic with respect to formation of the penetrative amphibolite facies foliation, which is inferred to have formed during decompression. The leucosomes commonly truncate boundaries between eclogite lenses and host gneisses, inducing retrogression of the eclogite facies host to amphibolite facies mineral assemblages by destabilization of clinopyroxene + garnet into amphibole + plagioclase. Population 2 is cut by undeformed pegmatites. Thus, population 2 was produced under amphibolite facies during deformation related to exhumation, before emplacement of the pegmatites.

Pegmatites of population 3 (Fig. 8) cut through all ductile structures, including foliation in the gneisses acquired during ductile amphibolite facies deformation, as well as the associated leucosomes. Thus, the undeformed pegmatites are intrusive (Fig. 7a). They may also penetrate eclogite facies bodies and there produce amphibolite facies retrogression fronts. The undeformed nature supports an interpretation that the pegmatites mark the end of penetrative ductile deformation during the exhumation history.

\section{PETROLOGY AND MICROTEXTURES}

SEM observations and microprobe analysis were performed at Camparis in the University Pierre et Marie Curie - Paris 6. Phase compositions were obtained by electron microprobe analysis (CAMECA SX50, SX100, and SXFive) operating in wavelength-dispersive mode. Major elements (Si, Al, Ti, Fe, Mn, Mg, Ca, Na, K, Cr) were analysed at $20 \mathrm{nA}, 15 \mathrm{KeV}$ with a focused electron beam using a mix of natural and synthetic standards and following the established analytical protocols.

\section{Host rocks}

Gneisses are quartzo-feldspathic rocks with garnet, biotite, white mica and amphibole. Apatite, zircon, titanite, Fe-Mg oxides and monazite are present as accessory minerals. Gneiss associated with leucosome and pegmatites show characteristic microtextures such as quartz 
grain at triple junctions (Fig. 9a) and elongated cuspate grains of plagioclase around garnet or amphibole (Fig. 9b). The gneiss sample NO10-17, associated with leucosome NO10-16 1 -g, was investigated in more detail.

At the thin-section scale, NO10-17 shows mineralogical and chemical zonation (Fig. $9 \mathrm{c} \& \mathrm{~d})$. The main part contains numerous small garnets $(100 \mu \mathrm{m})$ associated with $\mathrm{Fe}-\mathrm{Ti}$ oxides, clusters of clinopyroxene, orthopyroxene and amphibole. Quartz, plagioclase and biotite form the matrix. Two leucocratic veins composed of quartz and plagioclase with minor biotite, epidote and K-feldspar cut across the matrix. Leucocratic veins are made of euhedral plagioclase and quartz grains with minor acicular biotite and epidote; K-feldspar occurs locally. Asymmetric garnets outline the boundaries between matrix and the leucocratic veins (Fig. 9e \& f). Asymmetric garnets comprise a residual inclusion-rich core on the matrix side and an euhedral inclusion-free grain on the vein side (Fig. 9e \& f). The inclusion-rich cores are now positioned to one side of garnet grains. Asymmetric garnets have different compositions from matrix garnets and garnets from the deformed leucosome NO10-16 1-g. The significance of these asymmetric garnets will be discussed later.

Mafic rocks present triangular quartz grains at triple junctions and elongated cuspate plagioclase grains around garnet and amphibole. Samples NO11-31 (Flemsøy gabbro) and NO11-09 (Bud amphibolite) were investigated in detail.

NO11-31 corresponds to the "coronitic transitional stage" of Mørk (1985) with garnet (corona), clinopyroxene, orthopyroxene, phlogopite, plagioclase and amphibole. Early amphibole is part of the eclogite facies paragenesis but some amphibole appears as a secondary phase post-dating the eclogite facies assemblage (Mørk, 1985). Minor phases are rutile, apatite, zircon and ilmenite. Orthopyroxene and plagioclase symplectites constitute coronae around large aggregates of $\mathrm{Mg}-\mathrm{Fe}$ carbonate $(>50 \mu \mathrm{m})$. Carbonate appears to be a common and early phase in the samples studied. Plagioclase-bearing films are present between garnet and phlogopite and contain small euhedral grains of biotite $(<30 \mu \mathrm{m})$ and oxide $\left(<20 \mu \mathrm{m}\right.$; Fig. 10). The plagioclase films show Ca zonation from $\mathrm{An}_{29}$ to $\mathrm{An}_{17}$ in moving from the garnet to the phlogopite. Small grains of late biotite may be oriented parallel to the cleavage in phlogopite. Garnet shows dissolution textures in the vicinity of plagioclasebearing films (Fig. 10).

Amphibolite NO11-09 contains garnet, amphibole, plagioclase, and quartz. Plagioclase is $\mathrm{Ab}_{50-60} \mathrm{An}_{40-50}$. Amphiboles are tchermakite or edenite. Almandine-rich garnet $\left(\mathrm{Alm}_{50} \mathrm{Pyr}_{20} \mathrm{Grs}_{30} \mathrm{Sps}_{<1}\right)$ contains numerous inclusions, including multiphase inclusions that are not discussed further in the present study. Accessory phases are apatite, titanite and zircon.

\section{Multiphase inclusions in garnet from an eclogite facies lens}

Eclogite facies boudins from felsic gneiss at Svartberget (Fig. 1) contain garnet porphyroblasts associated with grain-scale light-coloured patches of plagioclase and quartz (Fig. 4a). The eclogite facies paragenesis in the mafic lens is garnet + omphacite + quartz \pm epidote. Biotite and white mica are sporadically present. This peak paragenesis is locally retrogressed to plagioclase + amphibole. Accessory minerals are oxides, apatite, rutile and titanite. Calcic plagioclase (up to $\mathrm{An}_{65}$ ) forms fine-grained intergrowths with quartz around eclogite facies garnets, visible as white films at the macroscale (Fig. 4b). Elongated feldspar grains are present between garnet and quartz. Eclogite facies garnets $\left(\mathrm{Alm}_{51-53} \mathrm{Pyp}_{22-24} \mathrm{Grs}_{23}\right.$ $\left.{ }_{25} \mathrm{Sps}_{1}\right)$ contain many inclusions, such as clinopyroxene $\left(\mathrm{Di}_{60} \mathrm{Jd}_{8} \mathrm{Hed}_{32}\right)$, in addition to multiphase inclusions. 
Seven multiphase inclusions from within garnet rims of the eclogite facies paragenesis have been studied in detail (Fig. 4). Externally, multiphase inclusions exhibit well defined crystal faces and negative crystal shapes (Fig. 4c \& d). They are surrounded by radial cracks in their host (Fig. 4d). The inclusions consist of plagioclase $+\mathrm{K}$-feldspar + biotite, sporadically containing antiperthite and quartz (Fig. 4c). Accessory minerals present in multiphase inclusions (such as apatite, rutile and Fe-Mg oxides; Fig. $4 \mathrm{~d} \&$ e) are the same as accessory minerals within the matrix of the rock. Fine-grained intergrowths of feldspar and quartz are observed in the multiphase inclusions. Plagioclase compositions differ from one inclusion to another $\left(\mathrm{Ab}_{48-65}\right.$ to $\left.\mathrm{An}_{52-33}\right)$, but are always Ca-rich. Only one biotite grain was successfully analysed, with $\mathrm{X}_{\mathrm{Mg}}$ of 0.53 (Table 2). The garnet host, with eclogite facies composition (Labrousse et al., 2004), is not zoned at its contact with the multiphase inclusions (representative compositions in Table 2 were analysed adjacent to inclusions).

It was only possible to estimate bulk compositions for two multiphase inclusions (Table 2), as phase analysis was difficult due to inclusion size. The bulk compositions were estimated from modal proportions (estimated by relative mineral proportion in thin section) combined with mineral compositions (mineral compositions in Table 2). However, for inclusion I8, K-feldspar and biotite were not properly analysed. Thus, the bulk composition was calculated from plagioclase, which represents $97.2 \%$ of the whole surface. Apatite was not considered as it probably did not crystallize from melt but rather acted as a nucleus for melt adsorption (J. Touret, pers. comm.). Both multiphase inclusions have $\mathrm{SiO}_{2}$ contents around $50 \mathrm{wt} \%$, high $\mathrm{CaO}$ contents $(12.17 \& 11.70 \mathrm{wt} \%)$ and comparatively low $\mathrm{Na}_{2} \mathrm{O}$ and $\mathrm{K}_{2} \mathrm{O}$ contents $\left(\mathrm{Na}_{2} \mathrm{O}<5 \mathrm{wt} \%, \mathrm{~K}_{2} \mathrm{O}<0.3 \mathrm{wt} \%\right.$; Table 2). Estimating bulk compositions from modal composition may introduce errors, as the volume ratio between phases may be different from surface ratio.

\section{Segregations, leucosomes and pegmatites}

Symplectite-bearing edges of the segregations, as represented by sample FLEM $111_{\mathrm{s}-\mathrm{m}}$, consist of fine-grained clinopyroxene-barroisite-plagioclase symplectites \pm orthopyroxene (Fig. 7b). Accessory phases are tourmaline, rutile, spinel, Fe-Ti oxides and monazite. Clinopyroxene is diopside-rich $\left(\mathrm{Di}_{50-60} \mathrm{Hed}_{50-40}\right)$, with highly variable jadeite content $(0-60 \%$, Fig. 11). The highest jadeite content is found in clinopyroxene inclusions in garnet $(60 \%$, Fig. 11). Garnet is almandine-rich $\left(\mathrm{Alm}_{60} \mathrm{Pyr}_{35} \mathrm{Grs}_{5}\right)$ with a lower grossular content than garnet in the eclogite facies gabbro $\left(\mathrm{Grs}_{8-35}\right.$, which is related to the degree of bulk rock eclogitization; Mørk, 1985) and a higher pyrope content $\left(\mathrm{Pyr}_{35}\right)$ than garnet in leucosomes and pegmatites $\left(\mathrm{Pyr}_{<24}\right.$, Fig. 11), but which is similar to the eclogite facies garnet within gabbro $\left(\mathrm{Pyr}_{26-56}\right.$; Mørk, 1985). Plagioclase grains close to garnet show thin bounding films $(\approx 1 \mu \mathrm{m})$, which have higher $\mathrm{Ca}$ contents. Ca-rich plagioclase is also present at boundaries between garnet and Na-rich plagioclase, where it is associated with small euhedral phlogopite $(10 \mu \mathrm{m})$, spinel and ilmenite grains. The pegmatite core, FLEM112 $2_{s-m}$, contains euhedral grains of albite $\left(\mathrm{Ab}_{99}\right)$ and quartz as well as carbonate veins (Fig. $7 \mathrm{c} \& \mathrm{~d}$ ). Elongated cuspate feldspars are present at grain boundaries, sometimes associated with round-shaped quartz (Fig. 7d). Carbonate veins have variable compositions, from $\mathrm{Ca}$-carbonate to $\mathrm{Fe}-\mathrm{Mg}$-carbonate, and they truncate feldspar grains (Fig. 7c).

Leucosomes of population 2 are mainly composed of quartz and two feldspars (modal composition in Table 1). Plagioclase composition is $\mathrm{Ab}_{67-84} \mathrm{An}_{33-16}$ and $\mathrm{K}$-feldspar composition is $\mathrm{Or}_{76-97}$. Garnets in most of the deformed leucosomes are rich in almandine $(\mathrm{Alm}>48)$ with variable amount of grossular $\left(\mathrm{Grs}_{0-35}\right)$ and pyrope $\left(\mathrm{Pyr}_{5-24}\right)$ from sample to

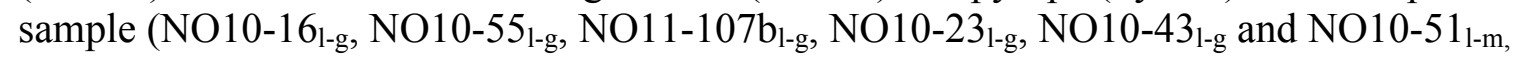
NO11-12 1 -m; Table 1 \& Fig. 11b). Garnets are homogeneous at the thin-section scale. NO10- 
$55_{1-g}$ contains garnet with high spessartine content $\left(\mathrm{Sps}_{63}\right)$ compared to other deformed leucosomes $\left(\mathrm{Sps}_{<1}\right)$ and a low almandine content $\left(\mathrm{Alm}_{25-27}\right.$, Fig. 11b). Seven deformed leucosomes contain up to $10 \%$ biotite with $\mathrm{Mg}$-number $\left(\mathrm{X}_{\mathrm{Mg}}=\mathrm{Mg} /(\mathrm{Mg}+\mathrm{Fe})\right)$ varying from 0.30 to 0.48 for samples hosted in gneiss, and from 0.50 to 0.57 for samples hosted in mafic

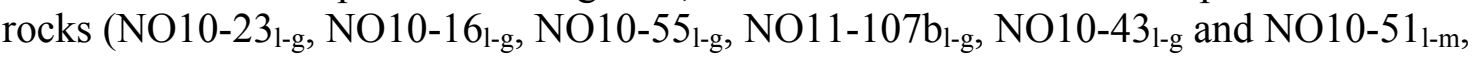
NO11-12 1 -m). Five leucosomes contain white mica with Si-apfu (atom per formula unit) of

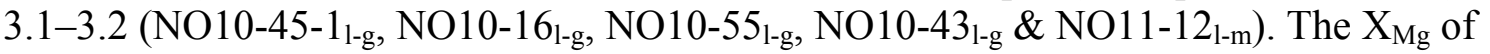
white mica varies from 0.20 to 0.43 . In NO10-16 1 , , white mica is present as tiny needles in the plagioclase grain. In other white mica-bearing samples, white mica is present as large inclusions in plagioclase (NO10-45-1 1 -g ) or as euhedral grains from $200 \mu \mathrm{m}$ to $1 \mathrm{~mm}$ (NO10$55_{1-\mathrm{g}}$ ), with no particular textural relationship with K-feldspar. In NO10-43 crystallized white mica is present. In sample NO10-55 euhedral white mica grains contain fibrolitic sillimanite. Two samples contain Ca-amphibole (5\% in the mode in NO11-107b $\mathrm{b}_{1 \mathrm{~g}}, 30 \%$ in NO10-51 1 - ; Table 2). Fe-Ti oxides, zircon, monazite and apatite are present as accessory minerals. Samples NO11-107 $\mathrm{b}_{1 \mathrm{~g}}$, NO10-51 1 -m, NO10-55 $5_{1-g}$ and NO10-16 $6_{1-g}$ contain rutile. Rutile in NO11-107b $b_{1-g}$ was found associated with destabilized titanite.

The undeformed pegmatites are composed of quartz, plagioclase and K-feldspar (modal composition in Table 1). Plagioclase is more albite-rich in gneiss-hosted samples than in samples hosted in mafic rocks (Ab99-73 vs. Ab 90-60 $_{90}$ respectively, Fig. 11a). K-feldspar has similar composition in both types $\left(\mathrm{Or}_{99-74}\right.$, Fig. 11a). Three pegmatites contain garnet $(\leq 5 \%$ in the mode, NO11-96 $6_{\mathrm{p}-\mathrm{g}}$, NO11-115 $\mathrm{p}$, and NO11-29p-m). Two samples have garnet with high spessartine (NO11-96 $6_{\mathrm{p}-\mathrm{g}}$ and NO11-115 $\mathrm{p}-\mathrm{m}, \mathrm{Sps}_{53-77}$ and $\mathrm{Sps}{ }_{40-43}$, respectively), low almandine $\left(\mathrm{Alm}_{<48}\right)$ and minor pyrope contents $\left(\mathrm{Pyr}_{1-8}\right)$ compared to other undeformed pegmatites $\left(\mathrm{Sps}_{<1}, \mathrm{Alm}_{>50}, \mathrm{Pyr}_{3-25}\right.$; Fig. 11b). High spessartine contents ( $\left.\mathrm{Sps}_{>53}\right)$ may represent magmatic garnet, crystallized from peraluminous granitic melt (Bea, 1996; Chen et al., 2013). Five samples contain up to $5 \%$ modal biotite with $X_{M g}$ varying from 0.54 to 0.63 in gneiss-hosted samples, but $\sim 0.42$ when hosted in mafic rocks (NO10-27 $7_{\mathrm{p} g}$, NO11-96 $6_{\mathrm{p}-\mathrm{g}}$, NO11-01 $1_{\mathrm{p}-\mathrm{g}}$, NO11-115 $\mathrm{p}$-m). Five pegmatites have white mica $(\mathrm{Si}=3.1-3.2$ apfu and $\mathrm{XMg}=$ $0.19-0.56$ ) in the mineral assemblage (NO10-60 $0_{\mathrm{p}-\mathrm{g}}$, NO11-96 $6_{\mathrm{p}-\mathrm{g}}, \mathrm{NO} 11-01_{\mathrm{p}-\mathrm{g}}, \mathrm{NO} 10-45-2_{\mathrm{p}-\mathrm{g}}$, NO11-115 $\mathrm{p}$ ). The same suite of accessory minerals is present as in the leucosomes of population 2. Three samples have rutile (NO11-01 $1_{\mathrm{p}-\mathrm{g}}$, NO11-12 $2_{\mathrm{p}-\mathrm{m}}$, NO11-115 $01_{\mathrm{p}-\mathrm{g}}$, rutile is present as exsolved grains in biotite and as small euhedral grains $(100 \mu \mathrm{m})$.

Leucosomes and undeformed pegmatites have subhedral to euhedral crystals of quartz and feldspars. Granitic veins with grain size smaller than the host are present between plagioclase grains (e.g. in NO10-27p-g, Fig. 7e). A film $(<20 \mu \mathrm{m})$ of sodium-rich plagioclase between plagioclase and muscovite was observed in NO10-23 1 -g (Fig. 4f). This film is similar to glass films observed in partially melted psammitic rocks or in partial melting experiments of natural samples (Holness, 2008). Moreover, more sodic rims around plagioclase grains are interpreted as crystallisation from a former melt on pre-existing grains (Vernon, 2011). Thus the observed plagioclase-bearing films may represent melt pseudomorphs.

\section{RELATIONSHIPS BETWEEN CHEMICAL COMPOSITION AND STRUCTURAL POSITION OF SEGREGATIONS, LEUCOSOMES AND PEGMATITES}

Bulk chemical compositions of selected samples were analysed on powders by ICP-MS and ICP-AES for major elements and trace elements at SARM (CRPG, Nancy; protocol in Carignan et al., 2001). Detection limits for major elements were better than $0.07 \mathrm{wt} \%$ with uncertainty $<5 \%$. Detection limits for trace elements are better than $10 \mathrm{ppm}$ with uncertainty $<15 \%$. 
The major and trace element compositions of segregations, leucosomes and pegmatites are listed in Table 1, together with modal compositions and CIPW (wt $\%$ ) normative components. Samples are divided in two groups: those hosted in gneisses, corresponding to deformed leucosomes and undeformed pegmatites, on one hand, and those hosted in mafic rocks, corresponding to samples from the three structural population on the other hand (from NO11-96 $6_{\mathrm{u}-\mathrm{g}}$ to NO10-23 $3_{\mathrm{lg}}$ and from NO11-115 $5_{\mathrm{u}-\mathrm{m}}$ to FLEM111 $1_{\mathrm{s}-\mathrm{m}}$ in Table 1).

Samples hosted in gneisses have silica contents between 65 and $76 \mathrm{wt} \%$. They are silica-saturated and slightly metaluminous to strongly peraluminous $(0.99<\mathrm{ASI}<1.39$; Table $1 \&$ Fig. 12). Samples have low $\mathrm{TiO}_{2}$ contents, below $0.5 \mathrm{wt} \%$, with $\mathrm{MgO}$ contents

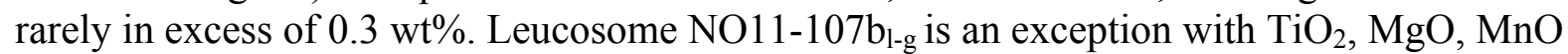
and $\mathrm{Fe}_{2} \mathrm{O}_{3}$ contents higher than other leucosomes in the gneisses (Table 1 \& Fig. 12). $\mathrm{K}_{2} \mathrm{O}$ content is high and variable, ranging from $2.5 \mathrm{up}$ to $8.3 \mathrm{wt} \%$ (Fig. 12). $\mathrm{Na}_{2} \mathrm{O}$ content varies from 2.3 to $4.9 \mathrm{wt} \%$ and is poorly correlated with the $\mathrm{SiO}_{2}$ content (Fig. 12). $\mathrm{CaO}$ is low, rarely exceeding $2 \mathrm{wt} \%$. In $\mathrm{Na}-\mathrm{Ca}-\mathrm{K}$ projection, compositions trend away from the $\mathrm{Na}-\mathrm{Ca}$ trondhjemite field toward the $\mathrm{K}$ apex, reflecting their variable $\mathrm{K}$ content and their low $\mathrm{Ca}$ content (Fig. 13). The NO11-107b $\mathrm{b}_{\text {-g }}$ leucosome does not belong to this trend and plots at higher Ca content.

Samples hosted in mafic rocks are less $\mathrm{SiO}_{2}$-rich than those hosted in gneisses, with $\mathrm{SiO}_{2}$ content between 55.59 and $75.4 \mathrm{wt} \%$. One sample, FLEM111 $1_{\mathrm{s}-\mathrm{m}}$, is silica-undersaturated with normative nepheline $(0.27 \%)$, others are silica-saturated; they are metaluminous to slightly peraluminous $(0.80<$ ASI $<1.05$; Table $1 \&$ Fig. 12$)$. These samples have variable $\mathrm{TiO}_{2}$ content, which remains low $(<1 \mathrm{wt} \%$, Fig. 12) and highly variable $\mathrm{MgO}$ content, ranging from 0.59 to $4.64 \mathrm{wt} \%$, that is inversely correlated with $\mathrm{SiO}_{2}$ (Fig. 12). Similarly, $\mathrm{CaO}$ content is inversely correlated with $\mathrm{SiO}_{2}$ and is generally high (up to $5.1 \mathrm{wt} \%$; Fig. 12). The pegmatite core (FLEM112 $2_{\mathrm{s}-\mathrm{m}}$ ) of the segregations is depleted in $\mathrm{MgO}, \mathrm{Fe}_{2} \mathrm{O}_{3}, \mathrm{MnO}, \mathrm{TiO}_{2}$, $\mathrm{CaO}$, and $\mathrm{K}_{2} \mathrm{O}$ and enriched in $\mathrm{SiO}_{2}$ and $\mathrm{Na}_{2} \mathrm{O}$ compared to the symplectite-bearing edge (FLEM111 1 s-m, Fig. 12). Similar variations are observed between NO11-12 1 -m and NO10-51 1-m, two deformed leucosomes from the Bud amphibolite. The $\mathrm{K}_{2} \mathrm{O}$ contents are lower than samples from the gneisses $(<2 \mathrm{wt} \%)$, with the exception of sample NO11-29p-m $(5.2 \mathrm{wt} \%$; Fig. 12), and are poorly correlated with $\mathrm{SiO}_{2}$, whereas $\mathrm{Na}_{2} \mathrm{O}$ contents are higher, varying from 2.8 to $8.8 \mathrm{wt} \%$ (Fig. 12). When projected in the $\mathrm{Na}-\mathrm{Ca}-\mathrm{K}$ diagram (Fig. 13), the samples define a trend away from the trondhjemite field toward the $\mathrm{Ca}$ apex, reflecting their low $\mathrm{K}$ content.

Thus, the two groups of samples are not only distinguished by their host but they also define different chemical trends, one between $\mathrm{Na}$ and $\mathrm{K}$ end-members, hereafter the Ca-poor group, and the other between $\mathrm{Na}$ and $\mathrm{Ca}$ end-members, hereafter the K-poor group. In the Capoor group, where both leucosome and pegmatite are present in one outcrop, leucosomes are enriched in Na compared to the pegmatites (e.g., NO10-45-1 $1_{1-\mathrm{g}}$ to NO10-45-2 $\mathrm{p}_{\mathrm{g}}$, NO10-23 $3_{1-\mathrm{g}}$ to NO10-27 p-g; black arrow Fig. 13). NO11-291-m belongs to the Ca-poor group, but it is a sample hosted in mafic rock. Within the K-poor group, the pegmatite core of the segregation is richer in $\mathrm{Na}$ and poorer in $\mathrm{K}$ than the symplectite-bearing edge (FLEM112 $2_{\mathrm{s}-\mathrm{m}} \mathrm{Vs}$. FLEM111 $1_{\text {s-m }}$; Fig. 13).

\section{TRACE ELEMENT COMPOSITIONS}

Chondrite-normalized and primitive mantle-normalized rare earth element (REE), and extended incompatible element patterns are shown in Figs. 14 to 17.

\section{Amphibolite facies gneisses and eclogite facies mafic host rocks}


To constrain trace element compositions of the amphibolite facies gneisses, 77 gneiss samples from the WGR were selected from the Norwegian Geological Survey (NGU) database. The gneisses have steep REE patterns with $(\mathrm{La} / \mathrm{Lu})_{\mathrm{N}}$ ratios ranging from 5.11 to 89.94 (Fig. 14a). A majority of gneiss samples display slight negative $\mathrm{Eu}$ anomalies, $\mathrm{Eu} / \mathrm{Eu}$ * varying from 0.35 to 0.91 . In the mantle-normalized trace element plots (Fig. 15a) all the gneisses exhibit significant enrichment in large ion lithophile elements (LILEs, e.g. $\mathrm{K}, \mathrm{Rb}, \mathrm{Ba}, \mathrm{Pb}$ ) but relative depletion in high field strength elements (HFSEs, Nb, Ta, Ti) and P. Such signatures are characteristic of igneous rocks having an upper crustal origin (Rudnick \& Gao, 2003).

Flemsøy gabbro sample NO11-31, the host of samples FLEM111 $1_{\text {s-m }}$ and FLEM112 ${ }_{\text {s-m }}$, is enriched in LREE relative to $\operatorname{HREE}\left((\mathrm{La} / \mathrm{Lu})_{\mathrm{N}}=4.18\right)$ without Eu anomaly (Fig. 16a). The REE content is similar to other compositions from the Flemsøy gabbro (Mørk \& Brunfeld, 1988). Amphibolite from Bud, NO11-09, is only slightly enriched in LREE relative to HREE $\left((\mathrm{La} / \mathrm{Lu})_{\mathrm{N}}=1.49\right.$; Fig. 16b). The Flemsøy gabbro (NO11-31, Fig. 17a) and Bud amphibolite (NO11-09, Fig. 17b) display relatively flat patterns on the incompatible element diagram, with positive $\mathrm{Ba}, \mathrm{Sr}$ and $\mathrm{K}$ anomalies and a negative $\mathrm{Nb}$ anomaly for the gabbro and negative $\mathrm{Th}$ anomaly and positive $\mathrm{K}$ and $\mathrm{Pb}$ anomalies for the amphibolite.

\section{Leucosomes and pegmatites hosted in gneisses}

Most of the samples in this group are enriched in LREE compared to HREE (Fig. 14b \& c). The $(\mathrm{La} / \mathrm{Nd})_{\mathrm{N}}$ ratios vary from 1 to 2.8 , but they display a wider range of HREE concentrations $\left((\mathrm{Gd} / \mathrm{Lu})_{\mathrm{N}}=0.2-8.0\right)$. The samples may be divided in two subgroups: those with high total REE content and negative Eu anomaly (NO11-107b $\mathrm{b}_{1-\mathrm{g}}$, N010-16 $6_{1-\mathrm{g}}$, N010-43 $\&$ NO11-96 $6_{\mathrm{p}-\mathrm{g}}$ ) and those with low total REE content and positive Eu anomaly (NO11-01 $1_{\mathrm{p}-\mathrm{g}}$,

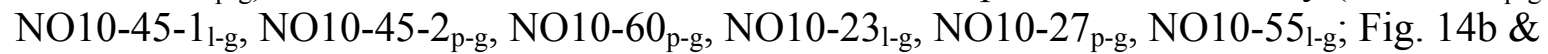
c). NO10-55 1-g, with low total REE content, is enriched in HREE compared to other samples $(\mathrm{Lu} / \mathrm{Gd})_{\mathrm{N}}=3.74$ vs. 0.4-2.2; Fig. 14c). The Eu poor group also exhibits negative $\mathrm{Sr}$ anomalies (Fig. 15b) whereas the Eu rich group shows generally higher Sr contents, (Fig. 15c). The variations in $\mathrm{Sr}$ and $\mathrm{Eu}$ are best explained by control by fractionation of and/or residual plagioclase (Bea et al., 1994).

\section{Segregations, leucosomes and pegmatites in mafic rocks}

In Flemsøy, FLEM111 $1_{\mathrm{s}-\mathrm{m}}$ and FLEM112 ${ }_{\mathrm{s}-\mathrm{m}}$, which represent the symplectite-bearing edge and pegmatite core of a representative segregation, are poor in total REE with respect to the gabbro (NO11-31: $\mathrm{La}_{\mathrm{N}}=51.44$; FLEM111: $\mathrm{La}_{\mathrm{N}}=15.35$; FLEM112: $\mathrm{La}_{\mathrm{N}}=11.84$; Fig. 16a). Both display high HREE/MREE ratios $\left((\mathrm{Lu} / \mathrm{Gd})_{\mathrm{N}}=2.3-2.5\right)$. FLEM112 ${ }_{\mathrm{s}-\mathrm{m}}$ is characterized by very low content of incompatible elements. Both have U-shaped patterns, which could be attributed to amphibole fractionation and/or residual amphibole (Klein et al., 1997; Fig. 16b). Both samples displays pronounced negative P anomaly (Fig. 17a), which may be due to apatite fractionation. Negative HFSE anomalies $(\mathrm{Nb}, \mathrm{Ti})$ are less pronounced but are systematic $\left(\mathrm{NO} 11-31(\mathrm{La} / \mathrm{Nb})_{\mathrm{N}}: 1.93 ; \operatorname{FLEM} 111(\mathrm{La} / \mathrm{Nb})_{\mathrm{N}}: 0,18 ; \operatorname{FLEM} 112(\mathrm{La} / \mathrm{Nb})_{\mathrm{N}}: 6,53\right.$; Fig. 17a). The LILE contents are variable but both samples show $\mathrm{U}$ and $\mathrm{Pb}$ anomalies.

In the Bud amphibolite, both leucosomes, NO10-51 1 , , and to a lesser extent NO11$12_{1-m}$, show steep REE patterns, with a wide range of LREE compared to a more limited range of HREE (Fig. 16b). Both are richer in LREE and MREE and poorer in HREE than the amphibolite. LILE enrichment is variable and moderate (see positive anomalies in Th and $\mathrm{U}$ for instance) and HFSE anomalies are also distinct, except for Ti (Fig. 17b). 


\section{DISCUSSION}

Based on structural and textural arguments the samples in this study were separated into three structural populations: segregations in mafic rocks, leucosomes in both gneisses and mafic rocks and undeformed pegmatites. There is no simple relationship between structural population and sample chemistry, and the samples correspond to two chemical groups that correlate with the nature of the host rock: the K-poor group of samples hosted in mafic rocks, which have compositions varying between $\mathrm{Na}$ - and $\mathrm{Ca}$-rich end-members, and the Ca-poor group of samples hosted in gneiss, which have compositions varying between $\mathrm{Na}$ - and K-rich end-members (Fig. 13). Multiphase inclusions occur in eclogite facies garnets in a mafic lens (Fig. 4).

In the following sections, we will first discuss the significance of the multiphase inclusions. Next we consider the significance of the whole-rock samples in terms of possible melt compositions, fractionated liquids or cumulates, to discriminate between the possible source(s) for melts. Finally, the geodynamic implications of the $P-T-\mathrm{X}$ conditions for partial melting recorded in the WGR will be discussed.

\section{Partial melting at HP}

The observed concordance between the metamorphic peak pressure in the northernmost part of the WGR with the water-saturated solidus of continental materials suggests that partial melting may initiate at the metamorphic pressure peak if $\mathrm{H}_{2} \mathrm{O}$-rich fluid is available (Fig. 1 in Labrousse et al., 2011). Observed multiphase inclusions may provide evidence for partial melting at $H P$. Indeed, these inclusions are very similar to multiphase nano-inclusions identified in granulites from India (negative crystal shape, well crystallized faces, radial cracks in the garnet, granitic assemblage; Cesare et al., 2009), which are interpreted as crystallized melts trapped during garnet growth (Cesare et al., 2009). Thus, the multiphase inclusions observed in one eclogite facies lens in felsic gneiss at Svartberget are interpreted as representing melt trapped during garnet growth at eclogite facies $P-T$ conditions. The presence of plagioclase within the assemblage of the multiphase inclusions is explained by crystallization of the melt below the jadeite + quartz $=$ plagioclase equilibrium $(1.2 \mathrm{GPa}$ at $800^{\circ} \mathrm{C}$ ), i.e. in the stability field of plagioclase. In situ leucosomes comprising plagioclase + quartz patches are associated with inclusion-bearing garnets (Fig. 4a), implying partial melting of the mafic lenses (Schröter et al., 2004). Taking the eclogite facies lens as the source of melt, it is relevant to compare the relative positions of the peak $P-T$ conditions (Moldefjord UHP domain: $820^{\circ} \mathrm{C}$ and 3.4-3.9 GPa, Terry et al., 2000b; Svartberget peridotite: $800^{\circ} \mathrm{C}$ and $3.4-5.5 \mathrm{GPa}$, Vrijmoed et al., 2006) and the basalt solidus. The Moldefjord $P-T$ path intersects the hydrated basalt solidus (Kessel et al., 2005) at UHP conditions (Fig. 18a). Thus, melt may have occurred at UHP conditions, as implied by the multiphase inclusions.

Although the multiphase inclusions are taken to be unequivocal evidence for the presence of melt at UHP conditions, they may represent a spatially and temporally limited melting event. Other indications for (U)HP partial melting come from leucosomes and pegmatites in the host gneissses. Gneiss sample NO10-17 preserves asymmetric garnets with residual inclusion-rich cores on one side and euhedral inclusion-free overgrowths associated with leucocratic veins on the other side (Fig. 9). Microstructures within leucocratic veins (euhedral plagioclase and quartz grains) indicate that they certainly crystallized from a melt and thus represent in situ leucosomes. Garnet asymmetry at vein-matrix boundaries suggests that part of the former garnet grain now represented by the residual inclusion-rich core was consumed during melting. Clinopyroxene-free layers close to the leucocratic veins indicate 
that clinopyroxene may also have been consumed during melting. These observations are in agreement with the following idealized partial melting reaction (Auzanneau et al., 2006):

$$
\mathrm{Phe}+\mathrm{Cpx}+\mathrm{Grt}+\mathrm{H}_{2} \mathrm{O}=\mathrm{M}(\mathrm{R} 1)
$$

Euhedral garnet overgrowths located opposite to the inclusion-rich cores may have crystallized from melt during decompression or they may have been formed by a garnetproducing reaction like the following idealized example (Auzanneau et al., 2006):

$$
\mathrm{Phe}+\mathrm{Cpx}+\mathrm{Qtz}=\mathrm{Grt}+\mathrm{P} 1+\mathrm{Bt}+\mathrm{M}(\mathrm{R} 2) .
$$

However, the deformed leucosome NO10-16 $6_{1-g}$ associated with gneiss sample NO10-17 contains $\mathrm{Qtz}+\mathrm{Pl}+\mathrm{Kfs}+\mathrm{Grt}+\mathrm{Bt}+\mathrm{Ms}$. Such biotite- and garnet-rich leucosomes are best explained by a peritectic reaction such as $\mathrm{R} 2$.

Comparing $P-T$ conditions for both reactions and $P-T$ estimates for the metamorphic peak recorded in the southernmost UHP domain in Fig. 1 enables us to constrain the $P-T$ history of NO10-17 and NO10-16 $6_{1-\mathrm{g}}$ (Fig. 18b). Indeed, the $P-T$ path of the Nordfjord UHP domain first intersects reaction R1 at HP conditions, providing an explanation for the leucocratic veins in NO10-17, and then reaction R2 at lower pressure, producing leucosome NO10-16 1 -g. Therefore, the succession of multiphase inclusions and melting reactions inferred from the paragenesis in the migmatites are strong arguments for melting initiated at UHP conditions, i.e. close to peak conditions.

\section{Significance of segregations, leucosomes and pegmatites}

Microstructures such as euhedral feldspars, granitic films, highly elongated cuspate feldspars and Ca-rich plagioclase rims or films in the samples of this study are characteristic of rocks formed by anatexis (Sawyer, 1999; Holness, 2008; Chen et al., 2013). Plagioclase films and elongated cuspate feldspars may represent pseudomorphs of former melt (Sawyer, 1999; Holness, 2008). However, sample composition may not correspond to the initial melt composition (Sawyer, 1987; Kriegsman et al., 2001; Solar \& Brown, 2001; Brown, 2002). It may have been modified by fractional crystallisation or interaction between initial melt and the host. Melting products affected by fractional crystallisation may either represent fractionated liquid, corresponding to initial melt minus early crystallized minerals, or cumulate, corresponding to early crystallized minerals plus variable amount of residual liquid (Sawyer, 1987). Most of the leucosomes and pegmatites in this study have REE patterns with a positive, or negative, Eu anomaly (Fig. $14 \mathrm{~b} \& \mathrm{c}$ ), probably due to plagioclase fractionation during crystallisation at LP. Fractionated liquids (or alternatively cumulates) are expected to show high (or low) total REE contents with negative (or positive) Eu anomaly.

Major element compositions of leucosomes and pegmatites in the gneisses (high $\mathrm{SiO}_{2}$ and $\mathrm{K}_{2} \mathrm{O}$ contents, low $\mathrm{MgO}$ and $\mathrm{FeO}$ contents), as well as their structural relationships with their host rocks, lead us to consider the surrounding gneiss as a potential starting material for partial melting. This hypothesis is supported by observations of microstructures characteristic of partial melting (triangular shaped grains at triple junctions, elongated cuspate feldspars, Fig. 9) in the surrounding gneiss. REE patterns in these leucosomes and pegmatites are consistent with the gneiss being their source (Fig. 14). Samples with high REE contents and

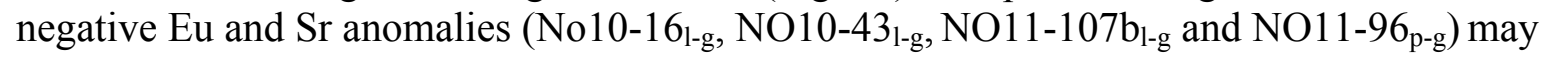
represent fractionated melt (Fig. 14b), whereas those with low REE contents and positive Eu

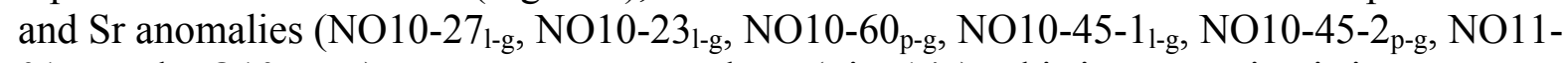
$01_{\mathrm{p}-\mathrm{g}}$ and NO10-551-g) may represent cumulates (Fig. 14c). This interpretation is in agreement with the observation of Na-rich plagioclase films around pre-existing plagioclase grains in NO10-23, putatively interpreted as crystallized from residual pore filling melt on pre-existing grains (Johnson et al., 2012). 
Major element compositions of segregations and pegmatites in mafic rocks, particularly their singular $\mathrm{Na}_{2} \mathrm{O}, \mathrm{K}_{2} \mathrm{O}$ and $\mathrm{CaO}$ contents (Fig. $12 \& 13$ ), together with their direct relationship with the mafic rocks, lead us to consider the mafic rocks as potential sources for the precursor melts. Plagioclase films containing neo-formed biotite (Fig 10) and multiphase inclusions (Fig. 4), which are interpreted to represent trapped melt, indicate that most of the mafic rocks in the study areas underwent partial melting. A fractionation hypothesis can be considered for the Bud and Svartberget localities. Both leucosomes from the Bud amphibolite belong to the K-poor chemical group and are enriched in REE compared to their host (NO11-09, Fig. 16b); thus, they were probably sourced from their host. Depletion in the HREE observed in NO11-121-m may be due to residual and/or fractionation of garnet, either of which implies HP conditions for such a bulk composition. Both core and edge of the segregation studied in the Flemsøy gabbro are depleted in REE compared to their host (Fig. 16a), which suggests that they probably represent cumulates. FLEM112, representing the core, is more depleted than FLEM111 from the symplectite-bearing marginal part (Fig. 16a), indicating that the core is more fractionated than the edge. This conclusion is in agreement with their structural position and their major element contents, the core being enriched in $\mathrm{SiO}_{2}$ and $\mathrm{Na}_{2} \mathrm{O}$ and depleted in $\mathrm{Fe}_{2} \mathrm{O}_{3}, \mathrm{MgO}, \mathrm{TiO}_{2}$ and $\mathrm{CaO}$ relative to the edge.

The compositions of these samples may have been modified by plagioclase fractionation during LP crystallization. No reaction front is observed around leucosomes, meaning that no reaction between leucosome and surrounding gneiss appear to have occurred. The same observation and conclusion can be made for pegmatites hosted in gneiss. Therefore, interaction between the segregated melt and its host remained limited. Where leucosomes and pegmatites are present in eclogite facies mafic rocks, they are associated with amphibolite facies retrogression in their hosts, representing a reaction front between host and the melt. Therefore, the segregations in the eclogite facies mafic rocks may represent products of the interaction between a silicate melt and its host. In contrast, microstructures observed within the gabbro (Fig. 10) indicate that the host has partially melted, consistent with an interpretation that the segregation here was locally produced, precluding any reaction between melt and host.

\section{Partial melting conditions in the WGR}

Although the compositions of melt-derived rocks were modified by plagioclase fractionation, as inferred from their REE contents, the magnitude of fractionation is not known. To investigate this issue, the compositions of the natural melt-derived rocks are compared with those of experimental glasses obtained by $\mathrm{H}_{2} \mathrm{O}$-present or $\mathrm{H}_{2} \mathrm{O}$-absent partial melting of metapelite and metabasite (Fig. $19 \& 20$ ). A good correlation between natural and experimental compositions may be taken to mean that fractionation remained limited (Patiño Douce \& Harris, 1998).

With the exception of the deformed gneiss NO11-107b $\mathrm{b}_{1-\mathrm{g}}$, for samples hosted in the gneisses there is a good correlation between experimental glass compositions obtained by partial melting of metapelite in the stability field of plagioclase (LP) and at higher pressures (HP) and the natural samples in Fig. 19. Moreover, in the $\mathrm{Na}-\mathrm{Ca}-\mathrm{K}$ projection, natural samples also have compositions similar to experimental glass (Fig. 21). The singularity of NO11-107b $b_{d-g}$ was already mentioned above in discussion of the Harker diagrams (Fig. 12). The lack of correlation between the composition of NO11-107 $\mathrm{b}_{\mathrm{d}-\mathrm{g}}$ and those of experimental glass means that either the composition of NO11-107 $b_{d-g}$ has been modified, i.e. it is not a melt-related composition anymore, or the partial melting source was not a metapelite. Similarly, the samples hosted in mafic rocks have compositions close to experimental glasses obtained by partial melting at HP of metabasites (Fig. $20 \& 21$ ). The good correlations 
between natural and experimental compositions for both metapelite and metabasite means that the fractionation observed in the natural samples remained low, but was sufficient to modify the REE patterns. Thus, experimental glass compositions produced at different conditions and for different starting materials may be compared with compositional trends for the natural melt-derived samples in WGR to constrain the sources of partial melting and perhaps the $P-T$ conditions of partial melting (Fig. 21). Neither sample NO11-107b $b_{\mathrm{d}-\mathrm{g}}$ nor the leucosomes or pegmatites present in eclogite facies rocks, which may have reacted with their host and produced the amphibolite facies retrograde metamorphism, are used for the comparisons.

For experiments run at high pressure (no plagioclase found in final assemblages, Fig. 21a), experimental dehydration melting products of metapelite cluster above $50 \% \mathrm{~K}$ (Patiño Douce \& Johnston, 1991), while the experimental products of water-present partial melting of metapelite, in the pressure range of $0.7-4.5 \mathrm{GPa}$ and for a temperature range of $750-1,050^{\circ} \mathrm{C}$, define a trend from Na-rich compositions $(\mathrm{Na}<75 \%)$ to K-rich compositions $(\mathrm{K}<70 \%$; Hermann \& Spandler, 2008). K-rich compositions, with $\mathrm{K}$ up to 4 atom $\%$ and $\mathrm{Na}<2$ atom $\%$, were obtained at high temperature $\left(1150^{\circ} \mathrm{C}\right)$, whereas Na-rich compositions, $\mathrm{Na}>4$ atom $\%$ and $\mathrm{K}<1.5$ atom $\%$, were obtained at temperature below $800^{\circ} \mathrm{C}$ (Hermann \& Spandler, 2008). The lowest temperatures correspond to temperatures recorded in the westernmost parts of the WGR, whereas the highest temperatures are not recorded in the WGR. For experiments run at low pressure with plagioclase present in final assemblages, dehydration partial melting of metapelite produced experimental glass compositions with variable $\mathrm{K}$ contents $(1<\mathrm{K}<2.37$ atom\%; Fig. 21b; Castro et al., 2000; Patño Douce \& Beard, 1995; Pickering \& Johnston, 1998). Experimental products of metapelite partial melting have compositions similar to the natural leucosomes and pegmatites hosted in gneisses (Fig. 21).

None of the reported metapelite partial melting experiments produced glass compositions that correspond to natural compositions hosted in mafic rocks. Experimental melts produced by partial melting of metabasalt in the pressure range of 1.2-3.2 GPa and for a temperature range of $840-1,150^{\circ} \mathrm{C}$ define a compositional trend from Na-rich compositions ( $>4$ atom\%) to Ca-rich compositions ( $>2$ atom\%; Fig. 21a; Rapp \& Watson, 1995; Prouteau et al., 2001). Water-present melting of basalt defines a continuous trend from Na-rich compositions ( $\mathrm{Na}>4$ atom\%) obtained at $3 \mathrm{GPa}$ for $T<1,000^{\circ} \mathrm{C}$, to Ca-rich compositions $\left(\mathrm{Na}<4\right.$ atom\%) synthesized down to $1 \mathrm{GPa}$ for $T<1,000^{\circ} \mathrm{C}$ (Prouteau et al., 2001).

Experimental melts obtained by dehydration melting cluster in the same compositional range, but were produced at higher temperatures $\left(T>1,000^{\circ} \mathrm{C}\right.$; Rapp \& Watson, 1995), such temperatures being too high for the WGR. The low-T experimental trend is comparable to the natural K-poor trend observed in the samples of this study.

Comparison between natural segregation, leucosome and pegmatite compositions with experimental glasses leads to the conclusion that although fractional crystallization occurred during formation of these rocks, its effect was limited. Furthermore, both chemical groups distinguished in the WGR are best explained by partial melting of two distinct sources. The $\mathrm{K}$-poor group hosted in mafic rocks is derived from partial melting of a mafic source, most probably the eclogite facies bodies present in the WGR, whereas the Ca-poor group hosted in gneisses was derived from partial melting of a metapelite source, i.e. the gneisses themselves.

Some further conclusions may be drawn from the comparison between natural samples and experimental glasses. In the temperature range recorded in the WGR, tonalitic melts $(\mathrm{Ca}-$ Na-rich and K-poor compositions) are only produced by HP water-present partial melting of a mafic source, which implies that Ca-rich natural compositions, even if now different from the pristine melt (based on REE patterns) were derived from HP water-present partial melting. Moreover, partial melting of both mafic and felsic rocks at realistic $P-T$ conditions for the WGR can only occur in the presence of $\mathrm{H}_{2} \mathrm{O}$-rich fluid (Fig. 21). Even if partial melting 
occurred as soon as (U)HP conditions were reached (deduced from multiphase inclusions and gneiss NO10-17), some part of the leucosomes and pegmatites now present represent products of LP partial melting, which implies that a melt was present over a wide range of pressure from the peak conditions to complete sub-solidus re-equilibration at amphibolite facies conditions.

\section{Geodynamic implications of partial melting}

The possibility of initiation of partial melting at moderate temperature $\left(<800^{\circ} \mathrm{C}\right)$ has great implications for crustal rheology. The presence of melt at LP conditions is known to have a weakening effect on the mechanical behaviour of the crust even for low percentages of melt, and this favours localization of strain (Rosenberg \& Handy, 2005; Wallis et al., 2005). The presence of melt at peak HP and UHP conditions, even if volumetrically limited, may act to decouple the continental crust from the subducting slab and initiate exhumation of the upward-buoyant crust. Thus, melting may play an important role in the exhumation of UHP rocks (Whitney et al., 2009).

Quantitative estimates of weakening necessary for exhumation of UHP rocks has been proposed on the basis of numerical modelling (Warren et al., 2008). In order to exhume rocks from pressures or temperatures relevant for the WGR, the effective viscosity of the subducted continental margin must be reduced by 1.4 to 1.7 orders of magnitude, which is close to the viscosity drop associated with partial melting in early channel flow models (Beaumont et al., 2001), and which may decoupling crustal dynamics from lithospheric boundary conditions. Theoretical flow laws for partially molten rocks (Paterson, 2001) relate effective viscosity to melt percentage, grain size and rock composition. For felsic rocks, with grain size between 0.1 and $1 \mathrm{~mm}$, the required viscosity drop is achieved for 4-7 vol.\% melt (Rosenberg et al., 2007). In the particular case of the WGR, the rate of partial melting at peak conditions cannot be directly assessed, but 4-7 vol.\% melt requires only limited melting.

Partial melting of distinct mafic and felsic sources at similar temperatures is only possible in the presence of $\mathrm{H}_{2} \mathrm{O}$-rich fluid. This implies that $\mathrm{H}_{2} \mathrm{O}$-rich fluid was available for reaction in the continental crust at depths appropriate to HP and UHP conditions. Water solubility in felsic melts has been estimated at between 20 and 29 vol. $\%$ at $2.5 \mathrm{GPa}$ pressure (Huang and Wyllie, 1981, Stern and Wyllie, 1973). The presence of 4-7 vol.\% watersaturated melt in the partially molten rock implies $0.8-2.0$ vol. $\% \mathrm{H}_{2} \mathrm{O}$-rich fluid in the felsic protolith prior to melting. This is a maximum value, since felsic melts are usually under saturated when produced at high temperature and reach saturation during cooling and crystallization (Johannes \& Holtz, 1990).

These values are in the range of water contents estimated for the crustal portion of oceanic slabs when subducted in the coesite stability field (0.7-2.0 vol.\%; van Keken et al, 2011), but their relevance for melting of a continental slab is unknown. Experimental constraints on phase transitions during continental subduction yield phase diagrams for $2 \mathrm{wt} \%$ $\mathrm{H}_{2} \mathrm{O}$ in continental crust (Irifune et al., 1994), suggesting that this amount of $\mathrm{H}_{2} \mathrm{O}$-rich fluid is reasonable. Several processes can be invoked to explain the presence of $\mathrm{H}_{2} \mathrm{O}$-rich fluid in such proportions. First, the fluid may be produced by prograde destabilization of hydrated minerals such as paragonite, glaucophane and chloritoid in the sub-solidus field (Schmidt et al., 2004; Labrousse et al., 2011). In the case of the WGR, it was demonstrated that hydrated minerals in the upper crust were destabilized prior to reaching the $\mathrm{H}_{2} \mathrm{O}$-present solidus (Labrousse et al., 2011). Fluid may also be produced by destabilization of hydrated phases in the sub-continental mantle, which is likely to occur at UHP conditions (Lenoir et al., 2000; Hattori \& Guillot, 2007). Geochemical tracing of these fluids during continental subduction is the next challenging task to be undertaken in the WGR. 


\section{CONCLUSIONS}

In UHP domains of the WGR, the presence of melt at peak pressure is directly implied by the presence of multiphase inclusions in eclogite facies garnets. Textures in surrounding gneisses are best explained by polybaric melting, with successive garnet-consuming and garnetproducing reaction at HP conditions. Melt-derived lithologies may be subdivided into three structural groups: segregations in mafic rocks, and leucosomes and undeformed pegmatites in both mafic rocks and gneisses. The chemistry of these rocks shows two trends: a first group with Ca-poor compositions, composed of samples hosted in gneisses, and a second group with K-poor compositions, composed of samples hosted in mafic rocks. Based on a comparison with experimental glasses obtained for $\mathrm{HP}_{2} \mathrm{O}$-present partial melting of metabasite and $\mathrm{HP}$ or LP partial melting of metapelite, the first group may be produced by partial melting of host gneisses and the second group may be produced by $\mathrm{H}_{2} \mathrm{O}$-present partial melting of mafic rocks at high pressure. An important implication of this study is that the whole of the WGR is likely to have undergone partial melting. Concomittant partial melting of the two different sources at the estimated peak temperatures is only possible in the presence of $\mathrm{H}_{2} \mathrm{O}$-rich fluid, implying that the continental crust was able to transport aqueous fluid to great depth. Melt produced by $\mathrm{H}_{2} \mathrm{O}$-present partial melting at metamorphic peak conditions weakens the continental crust, which enables it to decouple from the down-going lithospheric slab, initiating exhumation of $(\mathrm{U}) \mathrm{HP}$ eclogites, and explaining the apparent coincidence between the peak $P-T$ conditions and the wet solidus for granite in the WGR.

\section{Acknowledgements}

We thank E. Sawyer for thorough reviews and decisive suggestions and M. Brown for his atentive care and helpful ending of the manuscript. G. Stevens, T. Johnston and anonymous reviewer are also thanked. This project was benefited from INSU SYSTER program founding from CNRS and discussions within ERC project RHEOLITH Pi L. Jolivet \& E. Burov.

\section{REFERENCES}

Andersen, T.B. \& Jamtveit, B., 1990. Uplift of deep crust during orogenic extensional collapse: a model based on field studies in the Sogn-Sunnfjord region of Western Norway. Tectonics, 9, 1097-1111.

Andersen, T.B., Jamtveit, B., Dewey, J.F. \& Swensson, E., 1991. Subduction and eduction of continental crust; major mechanisms during continent-continent collision and orogenic extensional collapse: a model based on the south Norwegian Caledonides. Terra Nova, 3, 303-310.

Andersen, T.B., 1998. Extensional tectonics in the Caledonides of southern Norway, an overview. Tectonophysics, 285, 333-351.

Austrheim, H., Corfu, F., Bryhni, I. \& Andersen, T.B., 2003. The Proterozoic Hustad igneous complex: a low strain enclave with a key to the history of the Western Gneiss Region of Norway. Precambrian Research, 120, 149-157.

Auzanneau, E., Vielzeuf, D. \& Schmidt, M.W., 2006. Experimental evidence of decompression melting during exhumation of subducted continental crust. Contributions to Mineralogy and Petrology, 152, 125-148. 
Bea, F., Pereira, M.D. \& Stroh, A., 1994. Mineral/leucosome trace-element partitioning in a peraluminous migmatite (a laser ablation-ICP-MS study). Chemical Geology, 117, 291312.

Beaumont, C., Jamieson, R.A., Nguyen, M.H. \& Lee, B., 2001. Himalayan tectonics explained by extrusion of a low-viscosity crustal channel coupled to focused surface denudation. Nature, 414, 738-742.

Bittner, D. \& Schmelling, H., 1995. Numerical modelling of melting processes and induced diapirism in the lower crust. Geophysical Journal International, 123, 59-70.

Brown, M., 2002. Retrograde processes in migmatites and granulites revisited. Journal of Metamorphic Geology, 50, 25-40.

Bryhni, I., 1966. Reconnaissance studies of gneisses, ultrabasites, eclogites and anorthosites in outer Nordfjord, western Norway. Norges Geologiske Undersokelse, 241, p68.

Butler, J.P., Jamieson, R.A., Steenkamp, H.R. \& Robinson, P., 2013. Discovery of coesiteeclogite from the Nordøyane UHP domain, Western Gneiss Region, Norway: Field relations, metamorphic history, and tectonic significance. Journal of Metamorphic Geology, 31, 147-163.

Carignan, J., Hild, P., Mevelle, G., Morel, J. \& Yeghicheyan, D., 2001. Routine analysis of trace elements in geological samples using flow injection and low-pressure on-line liquid chromatography ICP-MS: a study of geochemical reference materials BR, DR-N, UB-N, AN-G and GH. Geostandards Newsletter, 25, 187-198.

Castro, A., Guillermo Corretgé, L., El-Biad, M., El-Hmidi, H., Fernández, C. \& Patiño Douce, A.E., 2000. Experimental constraints on Hercynian anatexis in the Iberian Massif, Spain. Journal of Petrology, 41, 1471-1488.

Cesare, B., Ferrero, S., Salvioli-Mariani, E., Pedron, D. \& Cavallo, A., 2009. "Nanogranite" and glassy inclusions: The anatectic melt in migmatites and granulites. Geology, 37, 627-630.

Chen, Y.X., Zheng, Y.F. \& Hu, Z., 2013. Synexhumation anatexis of ultrahigh-pressure metamorphic rocks: petrological evidence from granitic gneiss in the Sulu orogen. Lithos, 156-159, 69-96.

Corfu, F., Torsvik, T.H., Andersen, T.B., Ashwal, L.D., Ramsay, D.M. \& Roberts R.J., 2006. Early Silurian mafic-ultramafic and granitic plutonism in contemporaneous flysch, Magerøy, northern Norway: U-Pb ages and regional significance. Journal of the Geological Society, London, 163, 291-301.

Cuthbert, S.J., Carswell, D.A., Krogh Ravna, E. \& Wain, A., 2000. Eclogites and eclogites in the Western Gneiss Region, Norwegian Caledonides. Lithos, 52, 165-195.

Dobrzhinetskaya, L.F., Eide, E.A., Larsen, R.B., Sturt, B.A., Trønnes, R.G., Smith, D.C. , Taylor, W.R. \& Posukhova, T.V., 1995. Microdiamond in high-grade metamorphic rocks of the Western Gneiss region, Norway. Geology, 23, 597-600.

Engvik, A.K. \& Andersen, T.B., 2000. Evolution of Caledonian deformation fabrics under eclogite and amphibolite facies at Vårdalsneset, Western Gneiss Region, Norway. Journal of Metamorphic Geology, 18, 241-257.

Fossen, H., 2010. Extensional tectonics in the North Atlantic Caledonides: a regional view. Journal of Geological Society, London, Special Publication, 335, 767-793.

Foster, G., Parrish, R.R., Horstwood, M.S.A., Chenery, S., Pyle, J.M. \& Gibson, H.D., 2004. The generation of prograde $P$ - $T$-t points and paths; a textural, compositional, and chronological study of metamorphic monazite. Earth and Planetary Science Letters, 228, 125-142. 
Gibson, H.D., Carr, S.P., Brown, R.L. \& Hamilton, M.A., 2004. Correlations between chemical and age domains in monazite, and metamorphic reactions involving major pelitic phases: an integration of ID-TIMS and SHRIMPS geochronology with Y-Th-U X-ray mapping. Chemical Geology, 211, 237-260.

Gordon, S.M., Whitney, D.L., Teyssier, C. \& Fossen, H., 2013. U-Pb dates and trace-element geochemistry of zircon from migmatite, Western Gneiss Region, Norway: significance for history of partial melting in continental subduction. Lithos, 170-171, 35-53.

Hacker, B.R., Andersen, T.B., Johnston, S., Kylander-Clark, A.R.C., Peterman, E.M., Walsh, E.O. \& Young, D., 2010. High-temperature deformation during continental-margin subduction \& exhumation: The ultrahigh-pressure Western Gneiss Region of Norway. Tectonophysics, 480, 149-171.

Hattori, K.H. \& Guillot, S., 2007. Geochemical character of serpentinites associated with high- to ultrahigh-pressure metamorphic rocks in the ALPs, Cuba, and the Himalayas: recycling of elements in subduction zones. Geochemistry Geophysics Geosystems, 8, 127.

Hermann, J., Rubatto, D., Korsakov, A. \& Shatsky, V.S., 2001. Multiple zircon growth during fast exhumation of diamondiferous, deeply subducted continental crust (Kokchetav Massif, Kazakhstan). Contributions to Mineralogy and Petrology, 141, 66-82.

Hermann, J. \& Spandler, C.J., 2008. Sediment melts at sub-arc depths: an experimental study. Journal of Petrology, 49, 717-740.

Holness, M.B., 2008. Decoding migmatites microstructures. In: Working with migmatites (ed. Sawyer, E.W. \& Brown, M.). Mineral Association of Canada, Québec, Short Course, 38, 57-76.

Huang, W.L \& Wyllie, P.J., 1981. Phase relations of S-type granite with H2O to 35 kbar: Muscovite granite from Harney Peak, South Dakota. Journal of Geophysical Research, 86, 6115-6132.

Irifune, T., Ringwood, A.E. \& Hibberson, W.O., 1994. Subduction of continental crust and terrigenous and pelagic sediments: an experimental study. Earth and Planetary Science Letters, 126, 351-368.

Johannes, W. \& Holtz, F., 1990. Formation and composition of H2O-unsersaturated granitic melts. In: Ashworth, J.R. \&Brown, M., eds. High-temperature Metamorphism and Crustal Anatexis. The Mineralogical Society Series, 2, 87-104.

Johnson, T.E., Fischer, S., White, R.E., Brown, M. \& Rollinson, H.R., 2012. Archaean intracrustal differentiation from partial melting of metagabbro-Field and geochemical evidence from the Central Region of the Lewisian Womplex, NW Scotland. Journal of Petrology, 53, 2115-2138.

Kessel, R., Ulmer, P., Pettke, T., Schmidt, M.W. \& Thompson A.B., 2005. The water-basalt system at 4 to $6 \mathrm{GPa}$ : phase relations and second critical endpoint in a K-free eclogite at 700 to $1400^{\circ}$ C. Earth and Planetary Science Letters, 237, 873-892.

Klein, M., Stosch, H.G. \& Seck, H.A., 1997. Partitioning of high field-strength and rare-earth elements between amphibole and quartz-dioritic to tonalitic melts: An experimental study. Chemical Geology, 138, 257-27.

Kohn, M.J., Wieland, M.S., Parkinson, C.D. \& Upreti, B.N., 2005. Five generations of monazite in Langtang gneisses: implications for chronology of the Himalaya metamorphic core. Journal of Metamorphic Geology, 23, 399-406. 
Korksakov, A.V. \& Hermann, J., 2006. Silicate and carbonate melt inclusions associated with diamonds in deeply subducted carbonate rocks. Earth and Planetary Science Letters, 241, 104-118.

Krabbendam, M., Wain, A. \& Andersen, T.B., 2000. Pre-Caledonian granulite and gabbro enclaves in the Western Gneiss Region, Norway: indication of incomplete transition at high-pressure. Geological Magazine, 137, 235-255.

Kretz, R., 1983. Symbols for rock-forming minerals. American Mineralogist, 68, 277-279.

Kriegsman, L. M., 2001. Partial melting, partial melt extraction, and partial back reaction in anatectic migmatites. Lithos, 56, 75-96.

Krogh, T.E., Kamo, S.L., Robinson, P., Terry, M.P. \& Kwok K., 2011. U-Pb zircon geochronology of eclogites from the Scandian Orogen, northern Western Gneiss Region, Norway: 14-20 million years between eclogite crystallization and return to amphibolite-facies conditions. Canadian Journal of Earth Science, 48, 441-472.

Kylander-Clark, A.R.C., Hacker, B.R. \& Mattinson, J.M., 2008. Slow exhumation of UHP terranes: Titanite and rutile ages of the Western Gneiss Region, Norway. Earth and Planetary Science Letters, 272, 531-540.

Labrousse L., Jolivet L., Agard P., Hébert R. \& Andersen T.B., 2002. Crustal-scale boudinage and migmatization of gneiss during their exhumation in the UHP province of Western Norway. Terra Nova, 14, 263-270.

Labrousse, L., Jolivet, L., Andersen, T.B., Agard, P., Hébert, R., Maluski, H. \& Schärer, U., 2004. Pressure-temperature-time deformation history of the exhumation of ultra-high pressure rocks in the Western Gneiss Region, Norway. In: Gneiss domes in orogeny (ed. Whitney, D.L.). Geological Society of America, Special Paper, 380, 155-184.

Labrousse, L., Prouteau, G. \& Ganzhorn, A.C., 2011. Continental exhumation triggered by partial melting at ultrahigh pressure. Geology, 39, 12, 1171-1174.

Lang, H.M. \& Gilotti J.A., 2007. Partial melting of metapelites at ultrahigh-pressure conditions, Greenland Caledonides. Journal of Metamorphic Geology, 25, 129-147.

Lenoir, X., Garrido, C.J., Bodinier, J.L. \& Dautria, J.M., 2000. Contrasting lithospheric mantle domains beneath the Massif Central (France) revealed by geochemistry of peridotite xenoliths. Earth and Planetary Science Letters, 181, 359-375.

Mørk, M.B.E., 1985. A gabbro to eclogite transition on Flemsøy, Sunnmøre, Western Norway. Chemical Geology, 50, 283-310.

Mørk, M. B. E. \& Brunfelt, A. O., 1988. Geochemical comparisons of coronitic olivine gabbro and eclogites: metamorphic effects and the origin of eclogite protholiths (Flemsøy, Sunnmøre, Western Norway). Norsk Geologisk Tidskrift, 68, 51-63.

Paterson, M.S., 2001. A granular flow theory for the deformation of partially molten rock. Tectonophysics, 225, 51-61.

Patiño Douce, A.E. \& Johnston, A.D., 1991. Phase equilibria and melt productivity in the pelitic system: implications for the origin of peraluminus granitoids and aluminous granulites. Contributions to Mineralogy and Petrology, 107, 202-218.

Patiño Douce, A.E. \& Beard, J.S., 1995. Dehydration-melting of biotite gneiss and quartz amphibolite from 3 to $15 \mathrm{kbar}$. Journal of Petrology, 36, 707-738.

Patiño Douce, A.E. \& Harris, N., 1998. Experimental Constraints on Himalayan Anatexis. Journal of Petrology, 39, 689-710. 
Pickering, J.M. \& Johnston, D.A., 1998. Fluid-Absent Melting Behavior of a Two-Mica Metapelite: Experimental Constraints on the Origin of Black Hills Granite. Journal of Petrology, 39, 1787-1804.

Prouteau, G., Scaillet, B., Pichavant, M. \& Maury, R.C, 2001. Evidence of mantle metasomatism by hydrous silicic melts derived from subducted oceanic crust. Nature, 410, 197-200.

Rapp, R.P. \& Watson, E.B., 1995. Dehydration melting of metabasalt at 8-13 kbar: implications for continental growth and crust mantle recycling. Journal of Petrology, 36, 891-931.

Roberts, D. \& Gee, D.G., 1985. An introduction to the structure of the Scandinavian Caledonides. In: The Caledonide Orogen: Scandinavia and related areas (ed. Gee, D.G. \& Sturt, B.A.), 1, 55-68.

Roberts, D., 2003. The Scandinavian Caledonides: event chronology, palaeogeographic settings and likely modern analogues. Tectonophysics, 365, 283-299.

Root, D. B., Hacker, B. R., Gans, P. B., Ducea, M. N., Eide, E. A. \& Mosenfelder, J. L., 2005. Discrete ultrahigh-pressure domains in the Western Gneiss Region, Norway: implications for formation and exhumation. Journal of Metamorphic Geology, 23, 4561 .

Rosenberg, C.L. \& Handy, M.R., 2005. Experimental deformation of partially melted granite revisited: implications for the continental crust. Journal of Metamorphic Geology, 23, 19-28.

Rosenberg, C.L., Medvedev, S., \& Handy, M.R., 2007. Effects of Melting on Faulting and Continental Deformation. In: Tectonic faults, agents of change on a dynamic Earth (ed. Handy, M.R., Hirth, G. \& Hovius, N.). Berlin, Dahlem Workshop Reports, 95, 357-401.

Rudnik, R.L. \& Gao, S., 2003. Composition of the continental crust. In: Holland H.D. \& Turekian K.K., (Eds.). Treatise on Geochemistry, 3, 1-64.

Sawyer, E.W., 1987. The role of partial melting and fractional crystallization in determining discordant migmatite leucosome compositions. Journal of Petrology, 28, 445-473.

Sawyer, E.W., 1999. Criteria for the recognition of partial melting. Physical and chemical earth (A), 24, 269-279.

Schmidt, M.W., Vielzeuf, D. \& Auzanneau E., 2004. Melting and dissolution of subducting crust at high pressures: the key role of white mica. Earth and Planetary Science Letters, 228, 65-84.

Schröter, F.C., Stevenson, J.A., Dackzo, N.R., Clarke, G.L., Pearson, N.J. \& Klepeis, K.A., 2004. Trace element partitioning during high-P partial melting and melt-rock interaction; an example from northern Fiordland, New Zealand. Journal of Metamorphic Geology, 22, 443-457.

Sekine, T. \& Wyllie, P.J., 1982. The system granite-peridotite- $\mathrm{H}_{2} \mathrm{O}$ at $30 \mathrm{kbar}$, with applications to hybridization in subduction zone magmatism. Contributions to Mineralogy and Petrology, 81, 190-202.

Sizova, E., Gerya, T. \& Brown, M., 2012. Exhumation mechanisms of melt-bearing ultrahigh pressure crustal rocks during collision of spontaneously moving plates. Journal of Metamorphic Geology, 30, 927-955.

Smith, D.C., 1984. Coesite in clinopyroxene in the Caledonides and its implications for geodynamics. Nature, 310, 641-644. 
Solar, G.S. \& Brown, M., 2001. Petrogenesis of migmatites in Maine, USA: possible source of peraluminous leucogranite in plutions? Journal of Petrology, 42, 789-823.

Spencer, K.J., Hacker, B.R., Kylander-Clark, A.R., Andersen, T.B., Cottle, J.M., Stearns, M.A., Poletti, J.E. \& Seward, G.G.E., 2013. Campaign-style titanite U-Pb dating by ICP: implications for crustal flow, phase transformations and titanite closure. Chemical Geology, 341, 84-101.

Stern, C.R. \&Wyllie, P.J., 1973. Water-saturated and undersaturated melting relations of a granite to 35 kilobars. Earth and Planetary Science Letters, 18, 163-167.

Stöckhert, B., Duyster, J., Trepmann, C. \& Masonne, H.J., 2001. Microdiamond daughter crystals precipitated from supercritical $\mathrm{COH}+$ silicate fluids included in garnet, Erzgebirge, Germany. Geology, 29, 391-394.

Sun, S.S. \& McDonough, W.F., 1989. Chemical and isotopic systematics of oceanic basalts: implications for mantle composition and processes. Journal of Geological Society, London, Special Publications, 42, 313-345.

Taylor, J. \& Stevens, G., 2010. Selective entrainment of peritectic garnet into S-type granitic magmas: evidence from Archaean mid-crustal anatectites. Lithos, 120, 277-292.

Terry, M.P., 2000. Structural and thermal evolution of Baltica basement and infolded cover napes on Nordøyane and their bearing on mechanisms for production and exhumation of high-pressure rocks, Western Gneiss Region, Norway. Thesis, University of Massachusetts.

Terry, M.P, Robinson, P., Krogh Ravna, E.J., 2000. Kyanite eclogite thermobarometry and evidence for thrusting of UHP over HP metamorphic rocks, Nordøyane, Western Gneiss Region, Norway. American Mineralogist, 85, 1637-1650.

Teyssier, C. \& Whitney, D.L., 2002. Gneiss domes and orogeny. Geology, 30, 1139-1142.

Tucker, R.D., Robinson, P., Solli, A., Gee, D.G., Thornes, T., Krogh, T.E., Nordgolen, O. \& Bickford, M.E., 2004. Thrusting and extension in the Scandian hinterland, Norway: $\mathrm{New} \mathrm{U}-\mathrm{Pb}$ ages and tectonostratigraphic evidence. American Journal of Sciences, 304, 477-532.

Vanderhaeghe, O., 2001. Melt segregation, pervasive melt migration and magma mobility in the continental crust: The structural record from pores to orogens. Physic and Chemistry of the Earth (A), 26, 213-233.

Vanderhaeghe, O., 2009. Migmatites, granites and orogeny: flow modes of partially-molten rocks and magmas associated with melt/solid segregation in orogenic belts.

Tectonophysics, 477, 119-134.

van Keken, P.E., Hacker, B.R., Syracuse, E.M. \& Abers, G.A., 2011. Subduction factory: 4. Depth-dependent flux of $\mathrm{H} 2 \mathrm{O}$ from subducting slabs worldwide. Journal of Geophysical Research Solid Earth, 116, B01401.

Van Roermund, H.L.M., Carswell, D.A., Druny, M.R. \& Heijboer, T.C., 2002. Microdiamonds in a megacrystic garnet websterite pod from Bardane on the island of Fjortoft, western Norway: evidence for diamond formation in mantle rocks during creep continental subduction. Geology, 30, 959-962.

Vernon, R.H., 2011. Microstructures of melt-bearing regional metamorphic rocks. In: Origin and Evolution of Precambrian High-Grade Gneiss Terranes, with Special Emphasis on the Limpopo Complex of Southern Africa (ed. van Reenen, D.D., Kramers, J.D., McCourt, S., \& Perchuk, L.L.). Geological Society of America Memoire, 207.

Vielzeuf, D. \& Holloway, J.R., 1988. Experimental determination of the fluid-absent melting relations in the pelitic system. Contributions to Mineralogy and Petrology, 98, 257-276. 
Vrijmoed, J. C., Van Roermund, H. L. M. \& Davies, G. R., 2006. Evidence for diamondgrade ultra-high pressure metamorphism and fluid interaction in the Svartberget Fe-Ti garnet peridotite-websterite body, Western Gneiss Region, Norway. Mineralogy and Petrology, 88, 381-405.

Vrijmoed, J. C., Smith, D. C. \& van Roermund, H. L. M., 2008. Raman confirmation of microdiamond in the Svartberget Fe-Ti type garnet peridotite, Western Gneiss Region, Western Norway. Terra Nova, 20, 295-301.

Wain, A., 1997. New evidence for coesite in eclogite and gneisses: Defining an ultra-high pressure province in the Western Gneiss region of Norway. Geology, 25, 927-930.

Wallis, S., Tsuboi, M., Suzuki, K., Fanning, M., Jiang, L. \& Tanaka, T., 2005. Role of partial melting in the evolution of the Sulu (eastern China) ultrahigh-pressure terrane. Geology, $33,129-132$.

Warren, C.J., Beaumont, C. \& Jamieson, R.A., 2008. Deep subduction and rapid exhumation: Role of crustal strength and strain weakening in continental subduction and ultrahighpressure rock exhumation. Tectonics, 27, TC6002.

Whitney, D., Teyssier, C. \& Rey, P.F., 2009. The consequences of crustal melting in continental subduction. Lithosphere, 1, 323-327. 


\section{FIGURES}

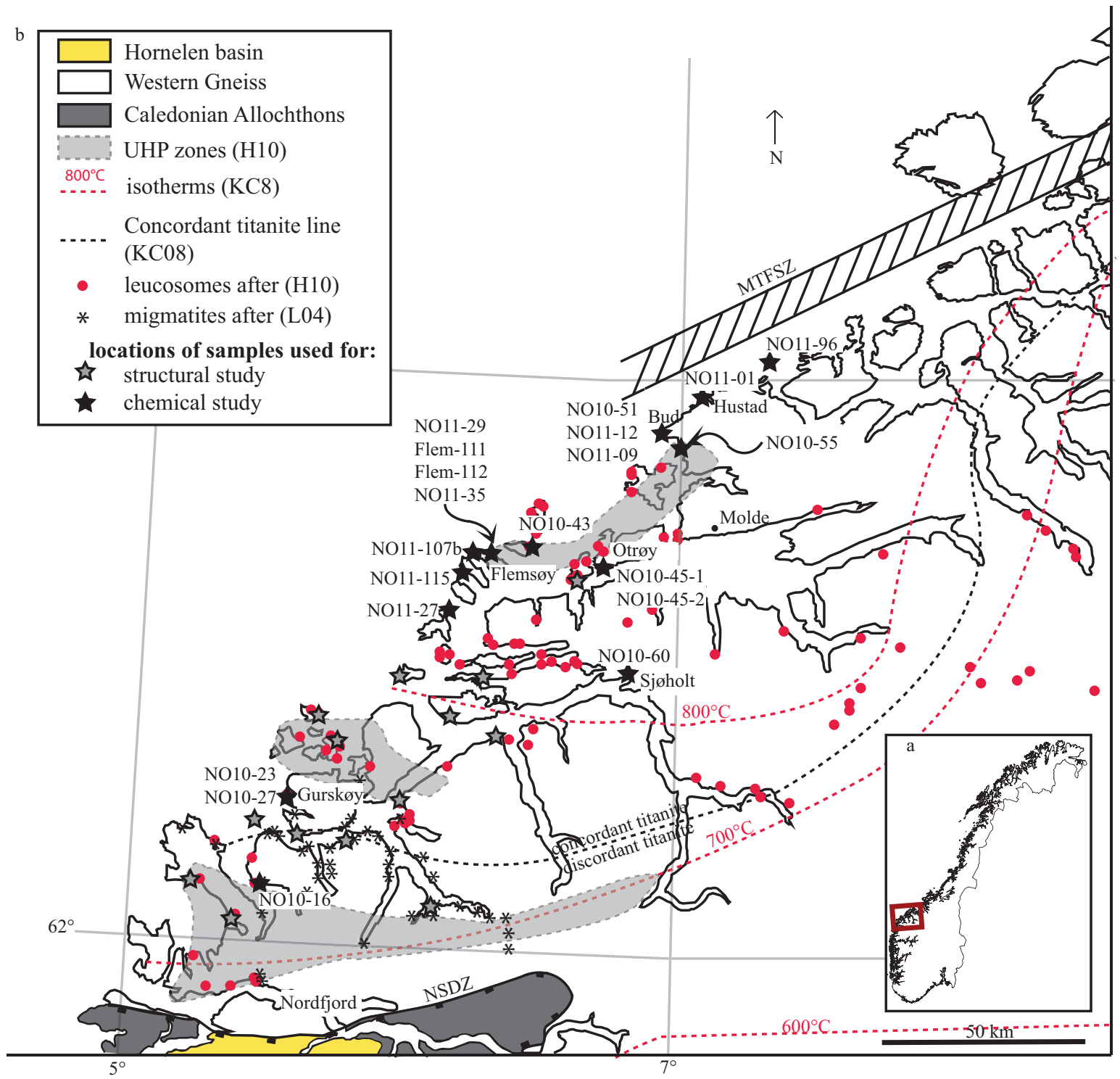

Fig. 1. Simplified geological map of the Western Gneiss Region with sample locations. (H10) $=$ Hacker et al. (2010), (KC08) = Kylander-Clark et al. (2008) and (L04) = Labrousse et al. (2004). 

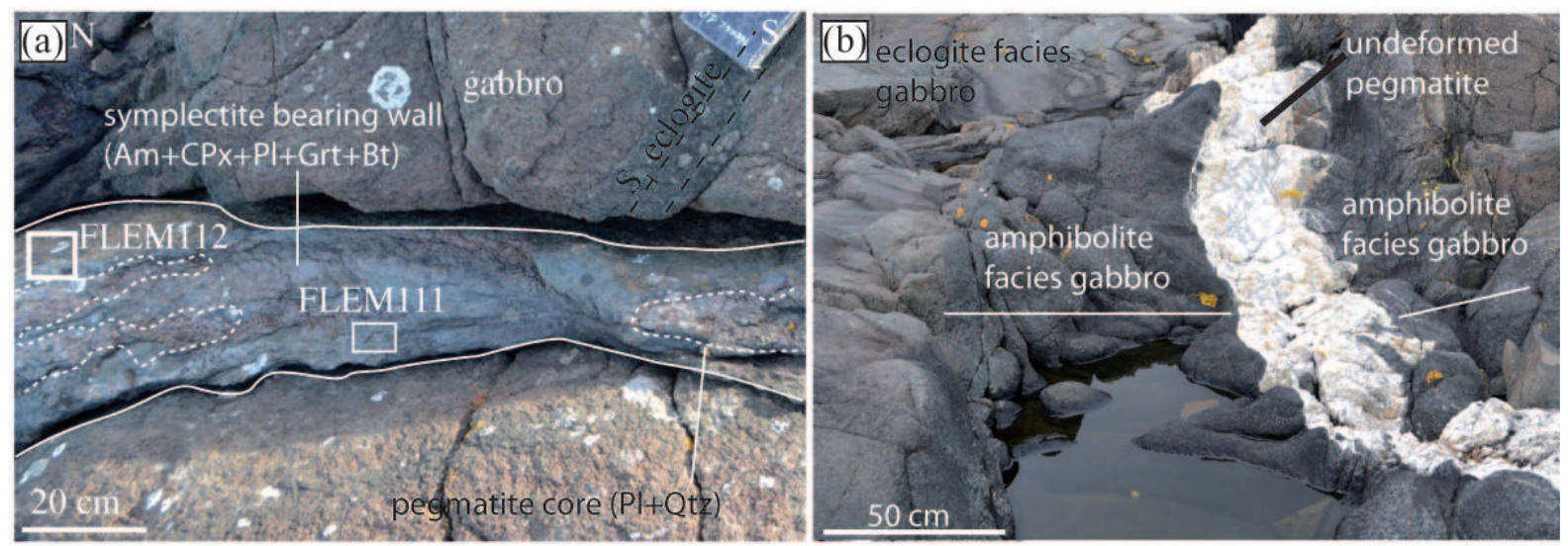

Fig. 2. Segregations in the mafic body of Flemsøy. (a) Symplectite-bearing edge and pegmatite core forming a segregation in the Flemsøy metagabbro. (b) Undeformed pegmatite associated with amphibole facies reaction in the host eclogite facies gabbro.
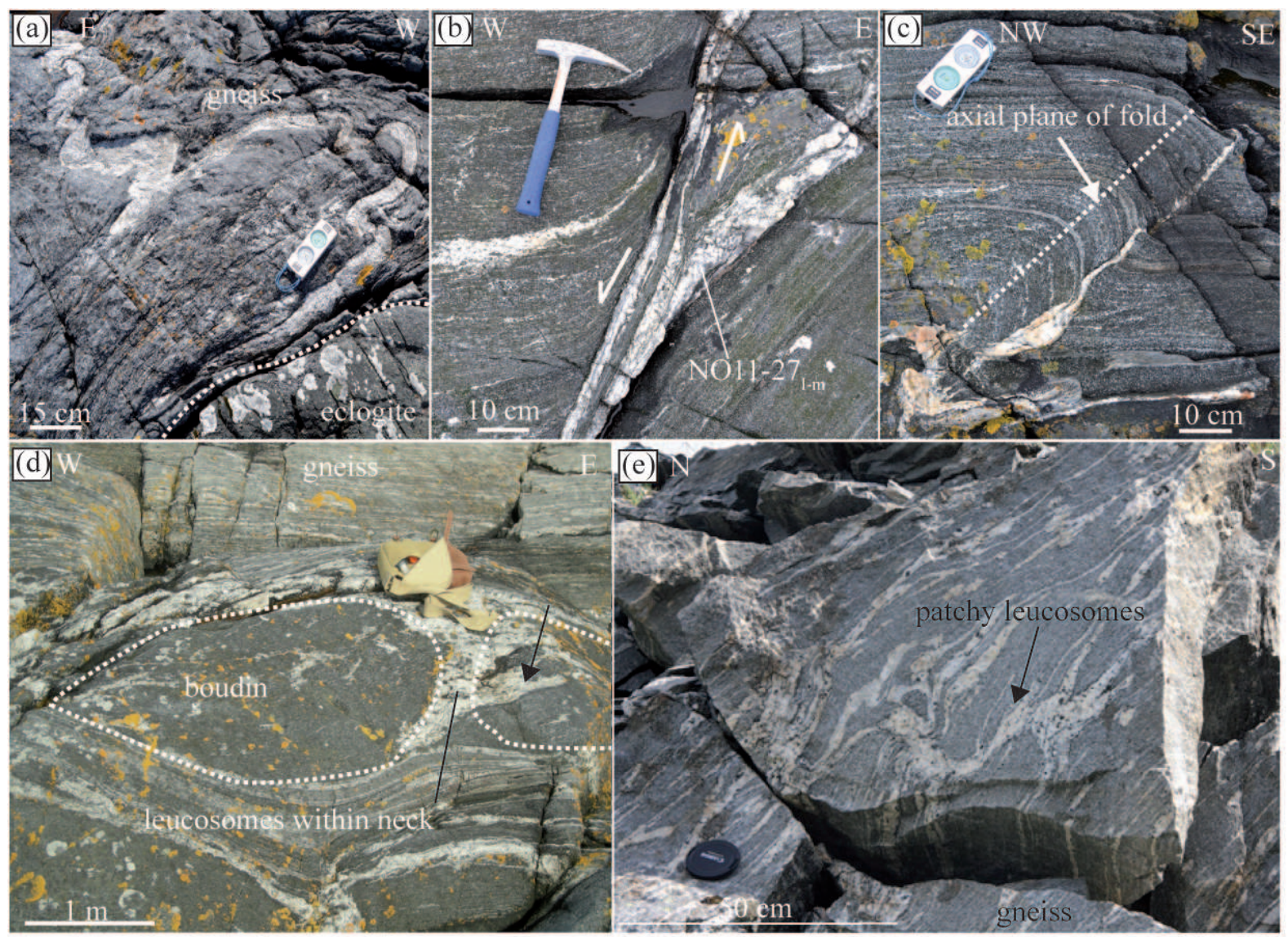

Fig. 3. Relationships between leucosomes and surrounding gneisses. (a) Folded leucosome. (b) Sheared leucosome; leucosome is also present inside shear zone. (c) Leucosomes located along the axial plane of folded gneiss. (d) Leucosome located in neck between two mafic boudins; leucosome also intruded the lens (black arrow). (e) Patchy network of leucosomes inside gneiss. See Table 1 for subscripts associated with names. 

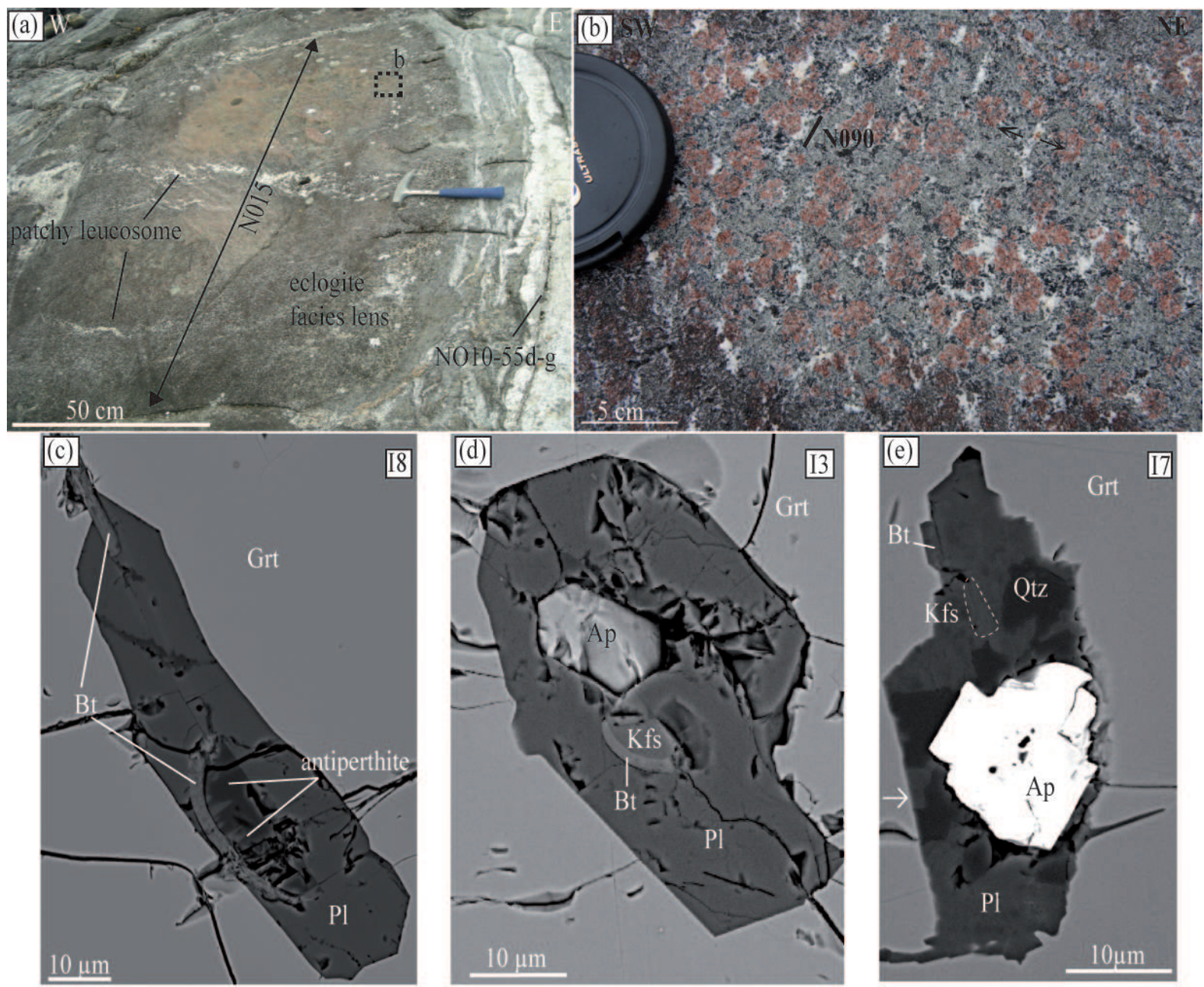

Fig. 4. Multiphase micro-inclusions in eclogite facies garnets of an eclogite lens, Svartberget. (a) Eclogite facies lens containing scattered light-coloured feldspathic films associated with garnets. (b) Close up of the light-coloured films associated with garnet porphyroblasts. (c) Micro-inclusion with smooth edges and an assemblage comprising two feldspars (plagioclase and antiperthite) and biotite. (d) Inclusion with a negative crystal shape and an assemblage comprising two feldspars, biotite and accessory apatite. The inclusion is surrounded by radial cracks in garnet. (e) Inclusions with intergrowth of quartz and plagioclase. Abbreviation after Kretz, 1983. 


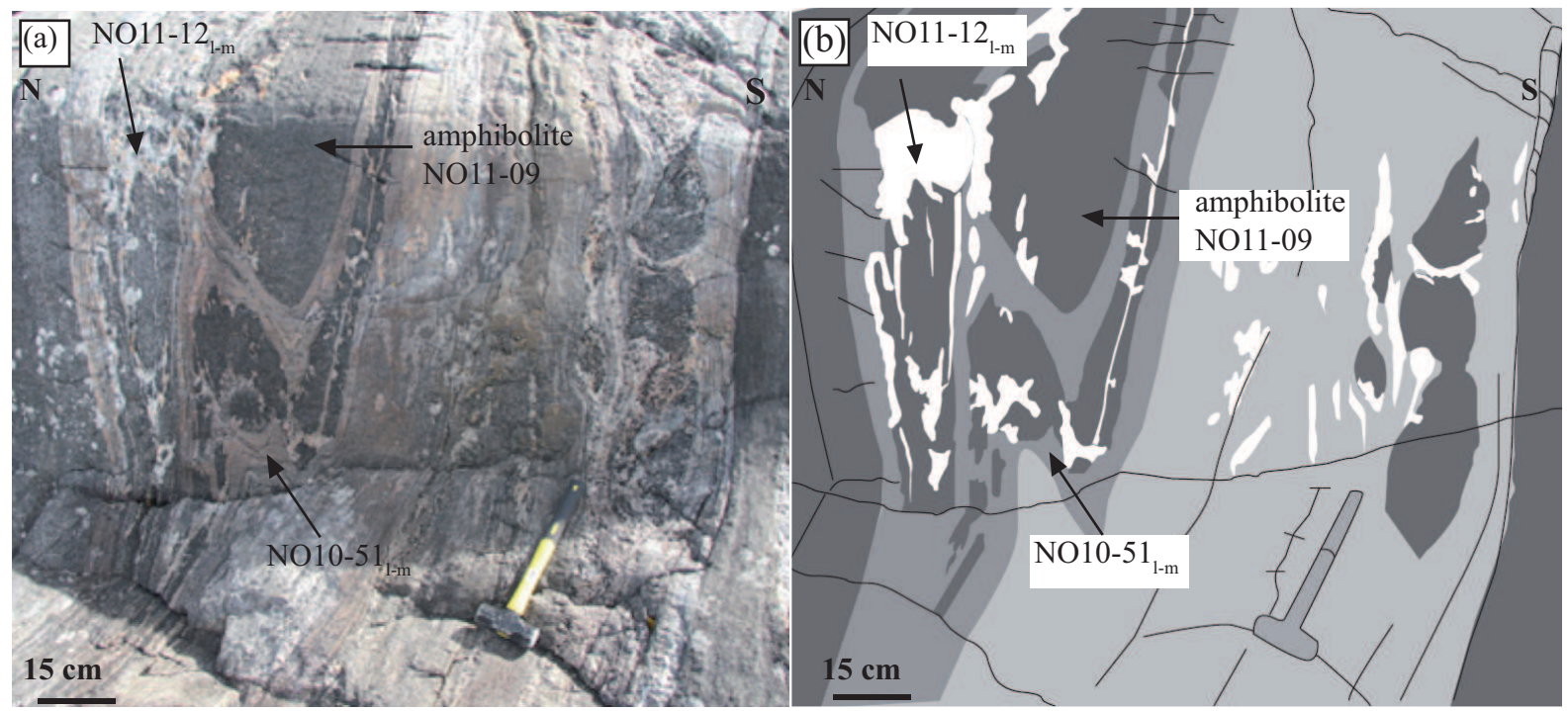

Fig. 5. Relationships between two deformed leucosomes and the Bud amphibolite. See Table 1 for subscripts associated with names.
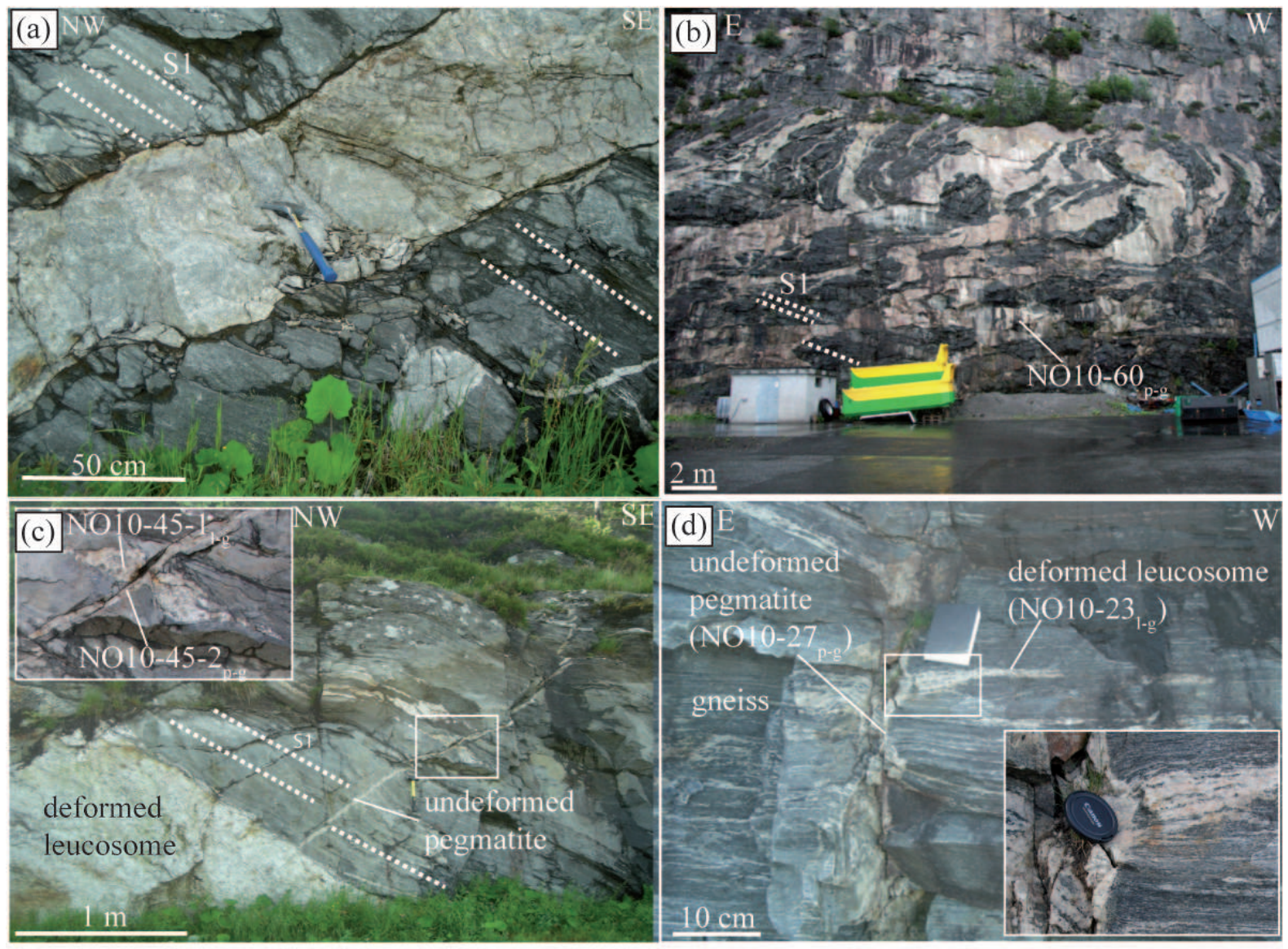

Fig. 6. Relationships between undeformed pegmatites and the surrounding gneisses. (a) A meter thick undeformed pegmatite cutting amphibolite facies foliation in gneiss, Otrøy. (b) Connected undeformed pegmatites forming a local vein network, Sjøholt. (c) \& (d) Relationships between undeformed pegmatites and deformed leucosomes in Otrøy and Gurskøy, respectively. See Table 1 for subscripts associated with names. 


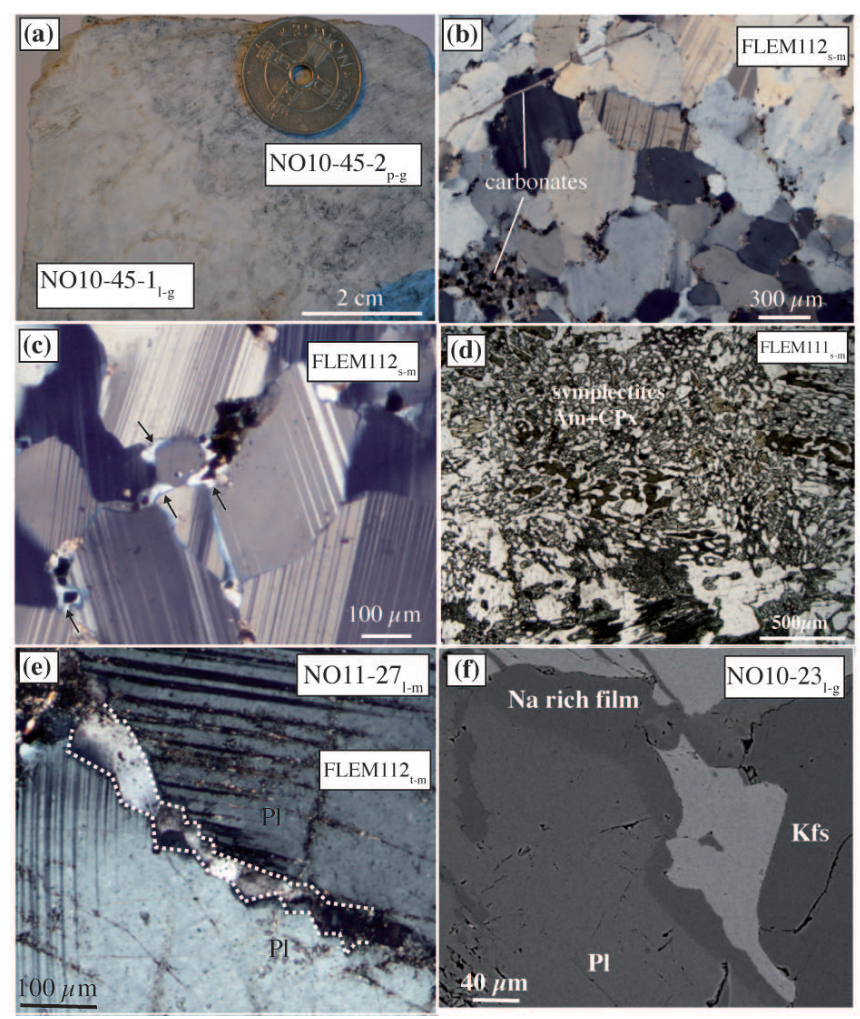

Fig. 7. Microtextures of samples. (a) Hand specimen showing relationship between a leucosome (NO10-45-1) and an undeformed pegmatite (NO10-45-2), as shown in Fig. 6c. (b) Textures of pegmatite core, Flemsøy. (c) Highly-elongated cuspate grain of quartz around plagioclase in pegmatite core. (d) Symplectite in symplectite-bearing edge of segregation in Flemsøy. (e) Films of small quartz grains between plagioclase in leucosome NO11-27 d-m. (f) Na-rich film between plagioclase and K-feldspar in leucosome. BSE image. See Table 1 for subscripts associated with names. 


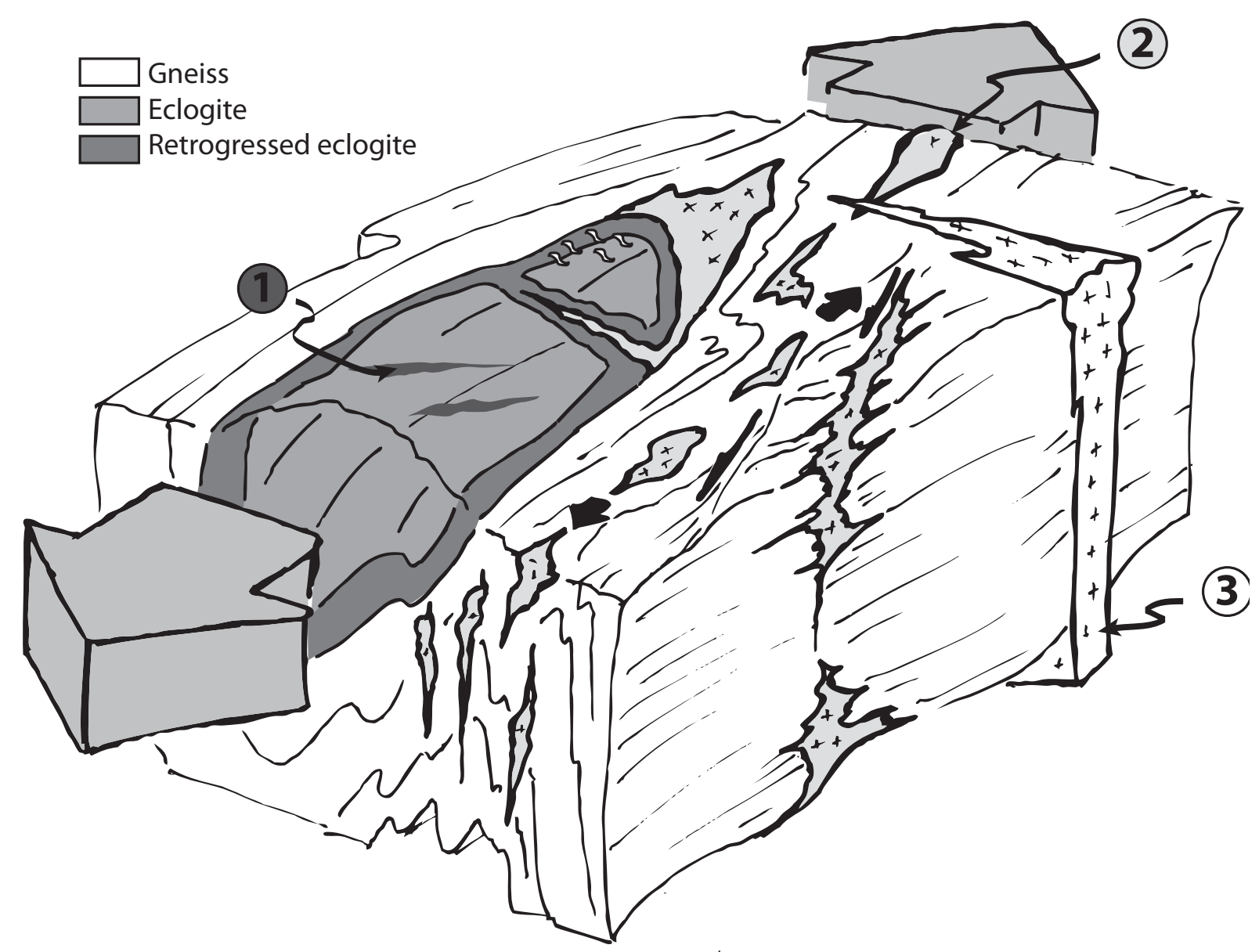

Fig. 8. Relationships between segregations, leucosomes and pegmatites, and the Caledonian structures. Numbers correspond to chronological order of formation (discussed further in the text). 

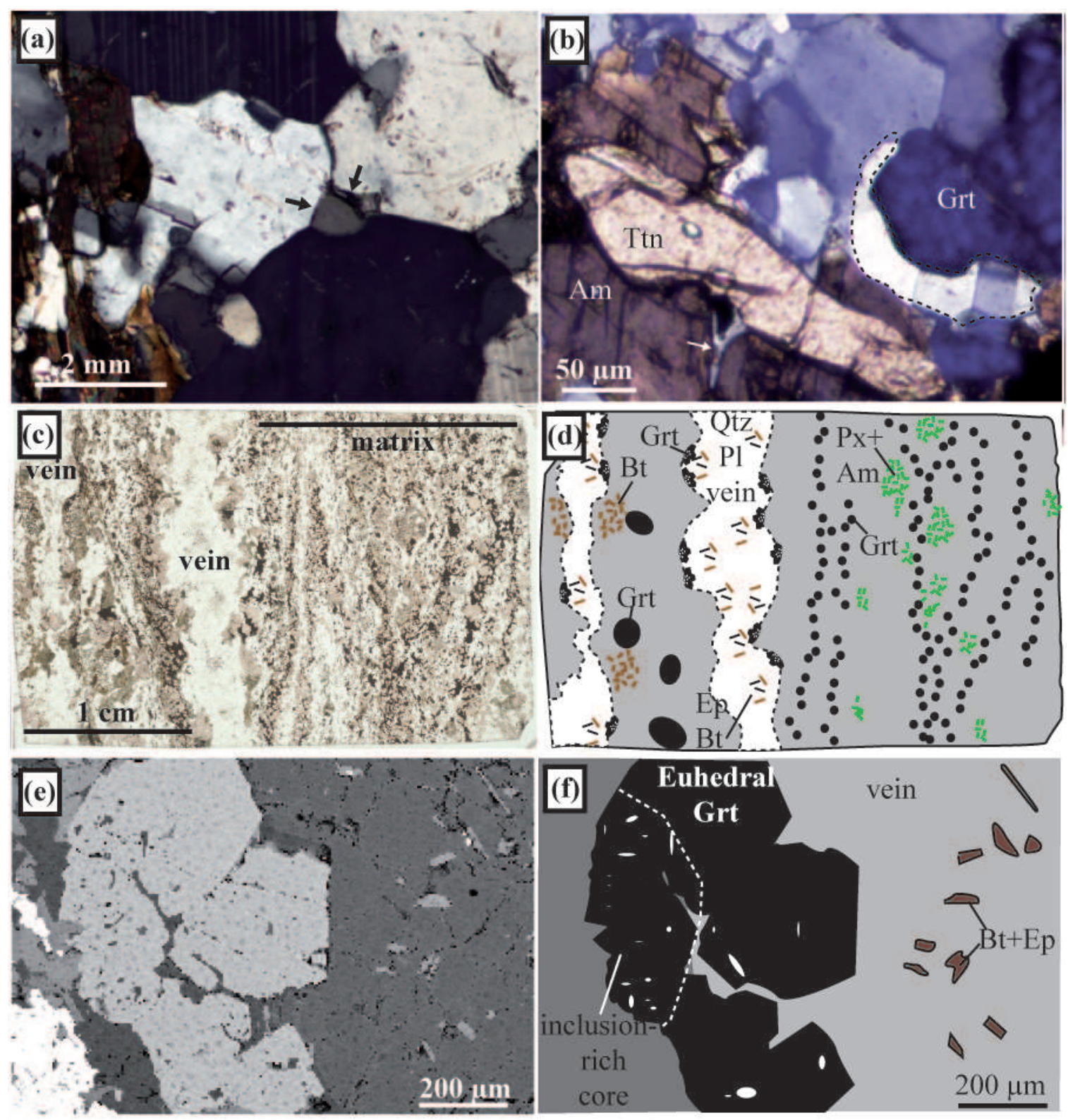

Fig. 9. Microstructures in gneiss. (a) Triangular shaped quartz grain at triple junction. (b) Elongated cuspate plagioclase around garnet and titanite. (c) Thin section image of NO10-17. (d) Interpretation of thin section. (e) \& (f) asymmetric garnet at leucocratic vein contact. 


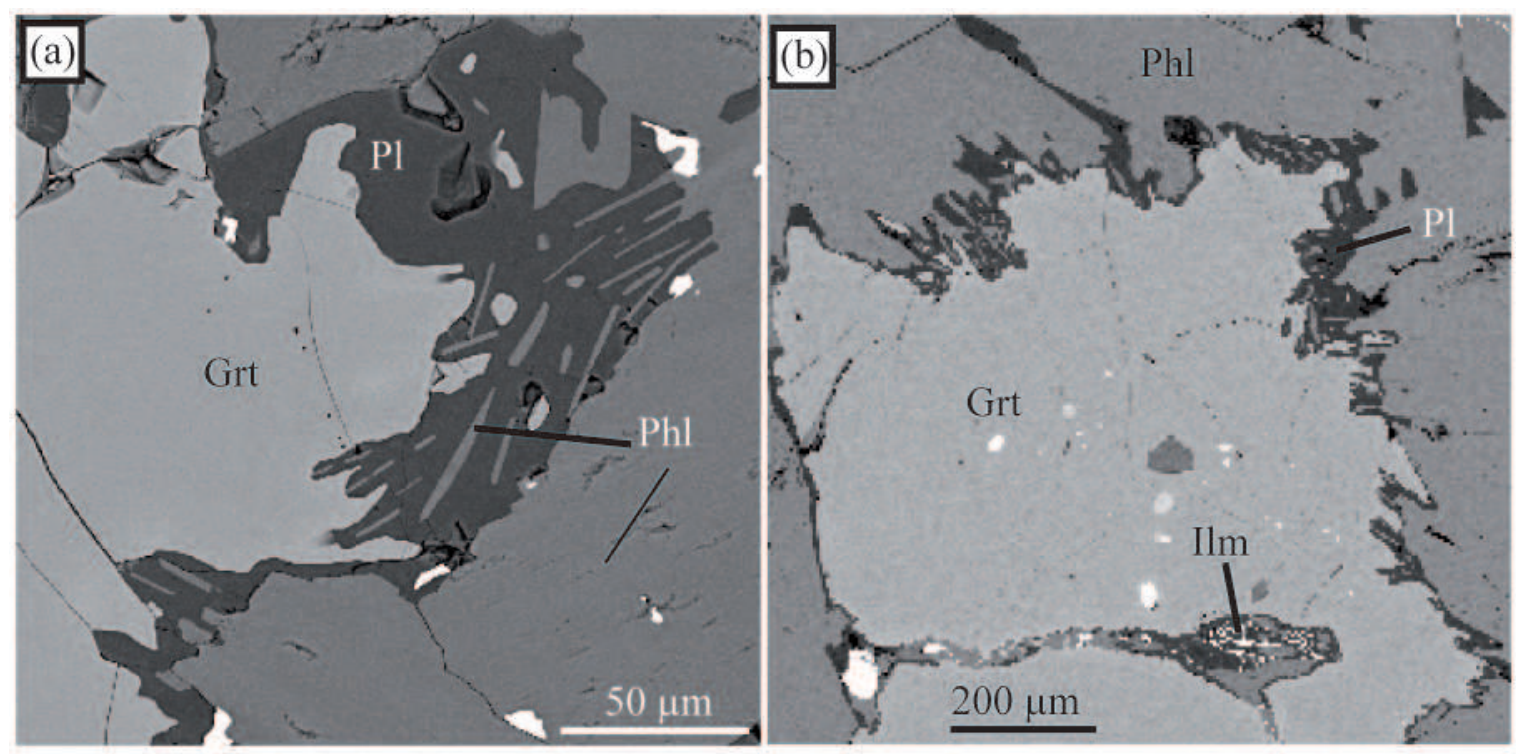

Fig. 10. Microstructures within Flemsøy gabbro. (a) Plagioclase film containing newly formed phlogopite associated with corrosion/dissolution texture of garnet. (b) Plagioclase film between garnet and phlogopite containing ilmenite and newly formed phlogopite. 
(a)

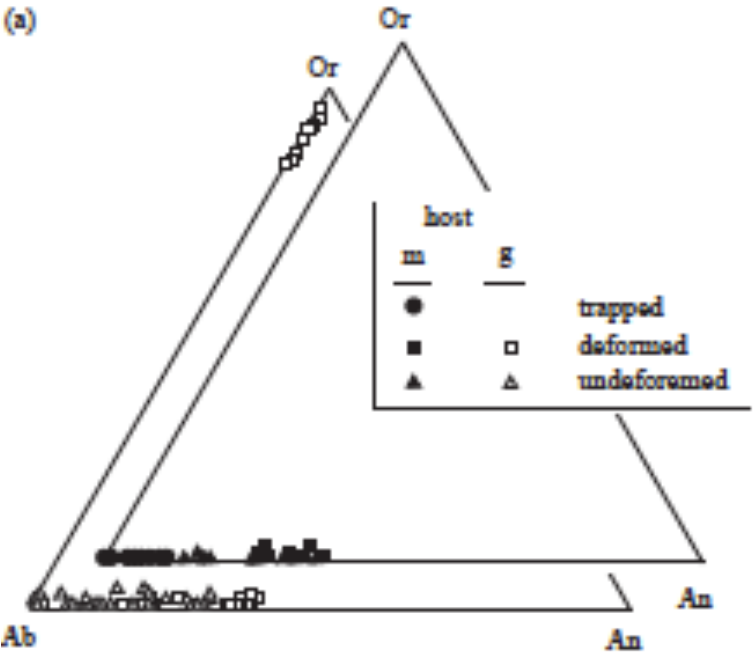

(b)

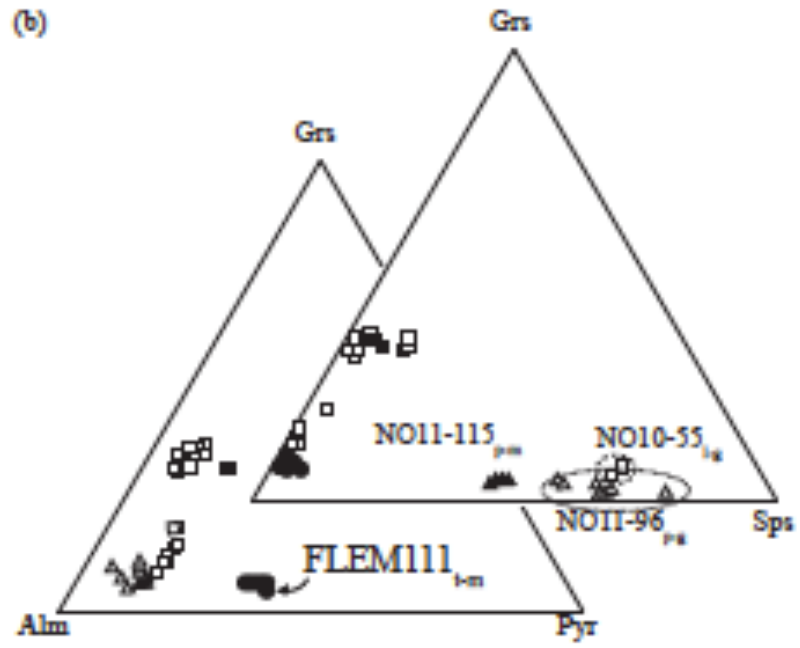

(c)

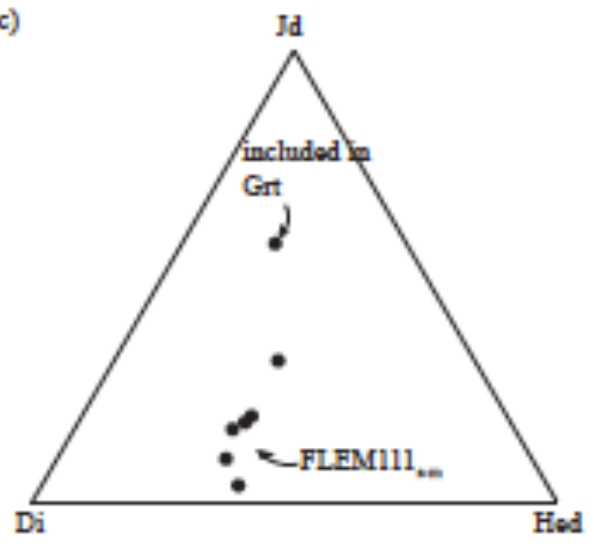

Fig. 11. (a) Feldspar, (b) garnet and (c) clinopyroxene compositions for different populations. See Table 1 for subscripts associated with names. 

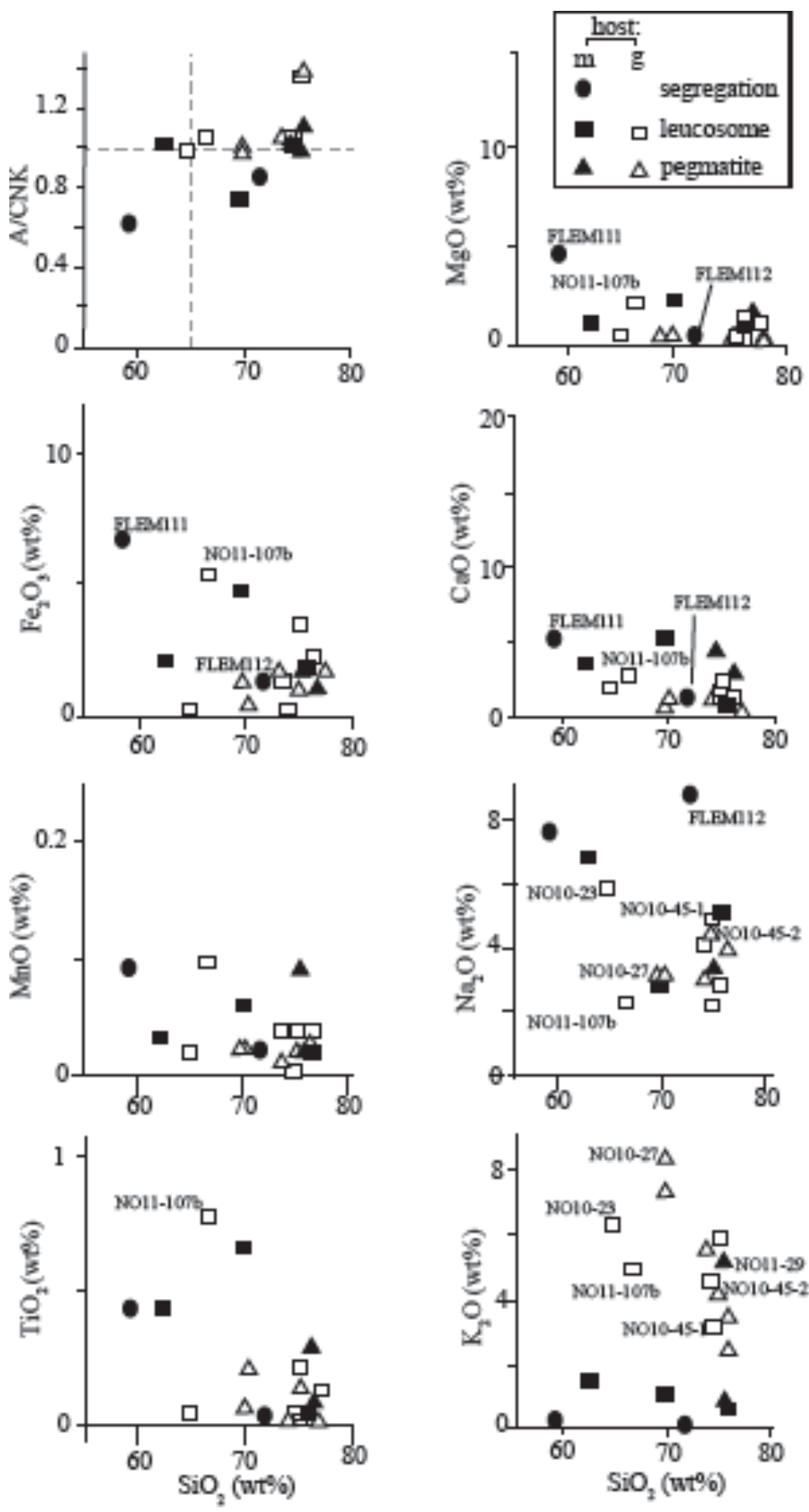

Fig. 12. Harker diagrams showing sample compositions; $\mathrm{m}=$ mafic rock, $\mathrm{g}=$ gneiss. 


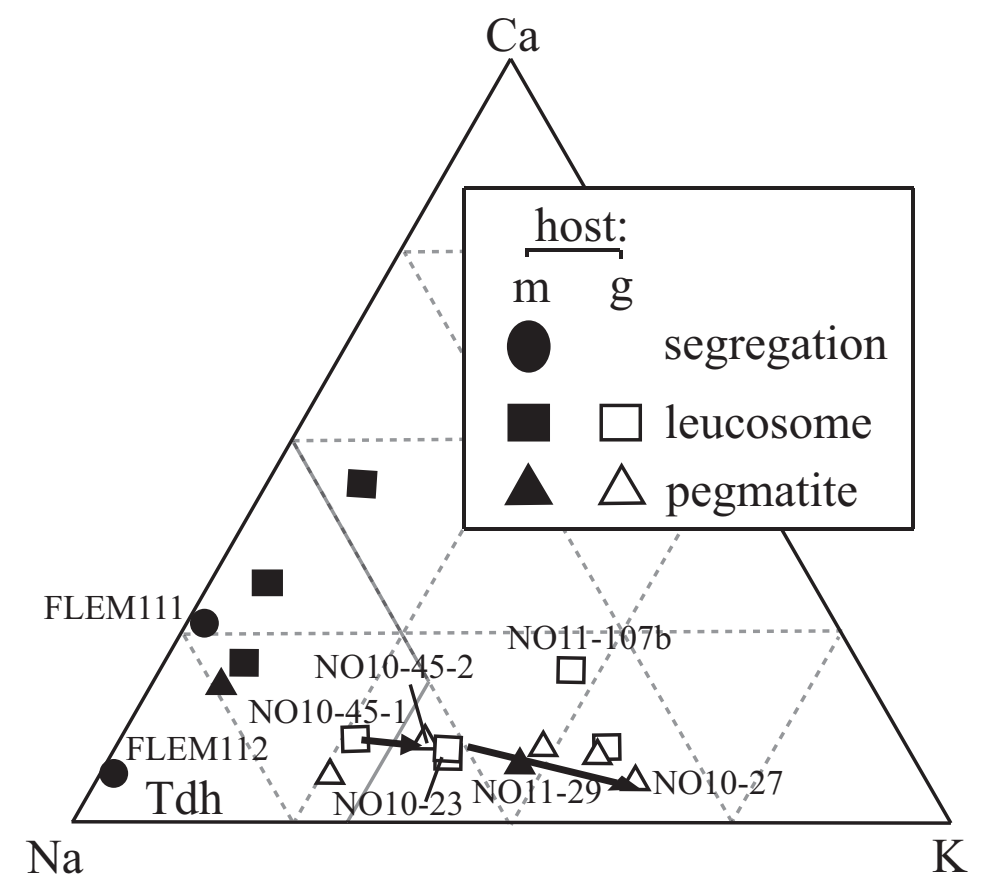

Fig. 13. Sample compositions plotted in a $\mathrm{Na}-\mathrm{K}-\mathrm{Ca}$ diagram expressed in atom\%. Black arrows indicate evolution from leucosome to pegmatite at the same outcrop; $\mathrm{m}=$ mafic, $\mathrm{g}=$ gneiss. 
(a)

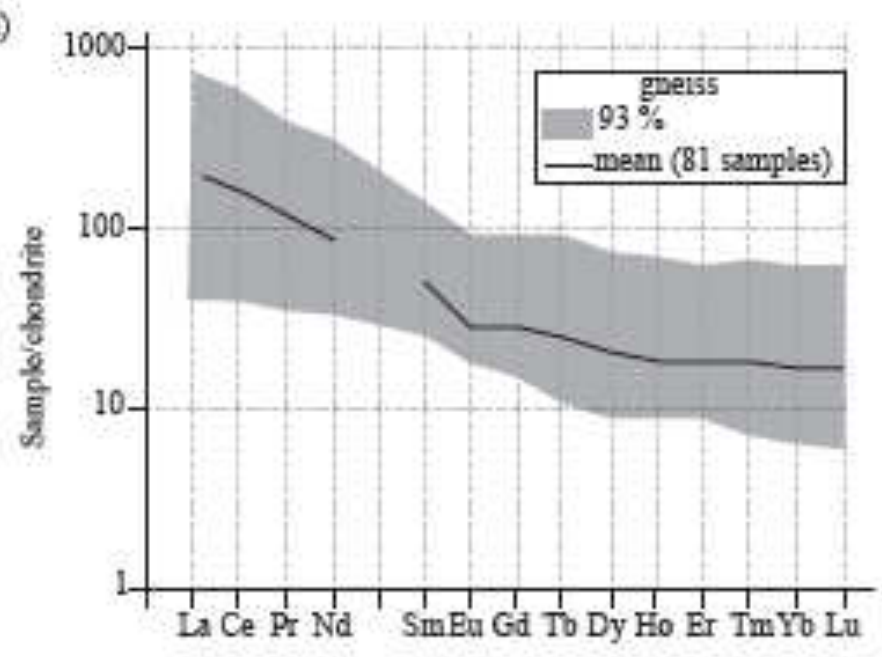

(b) High REE contents
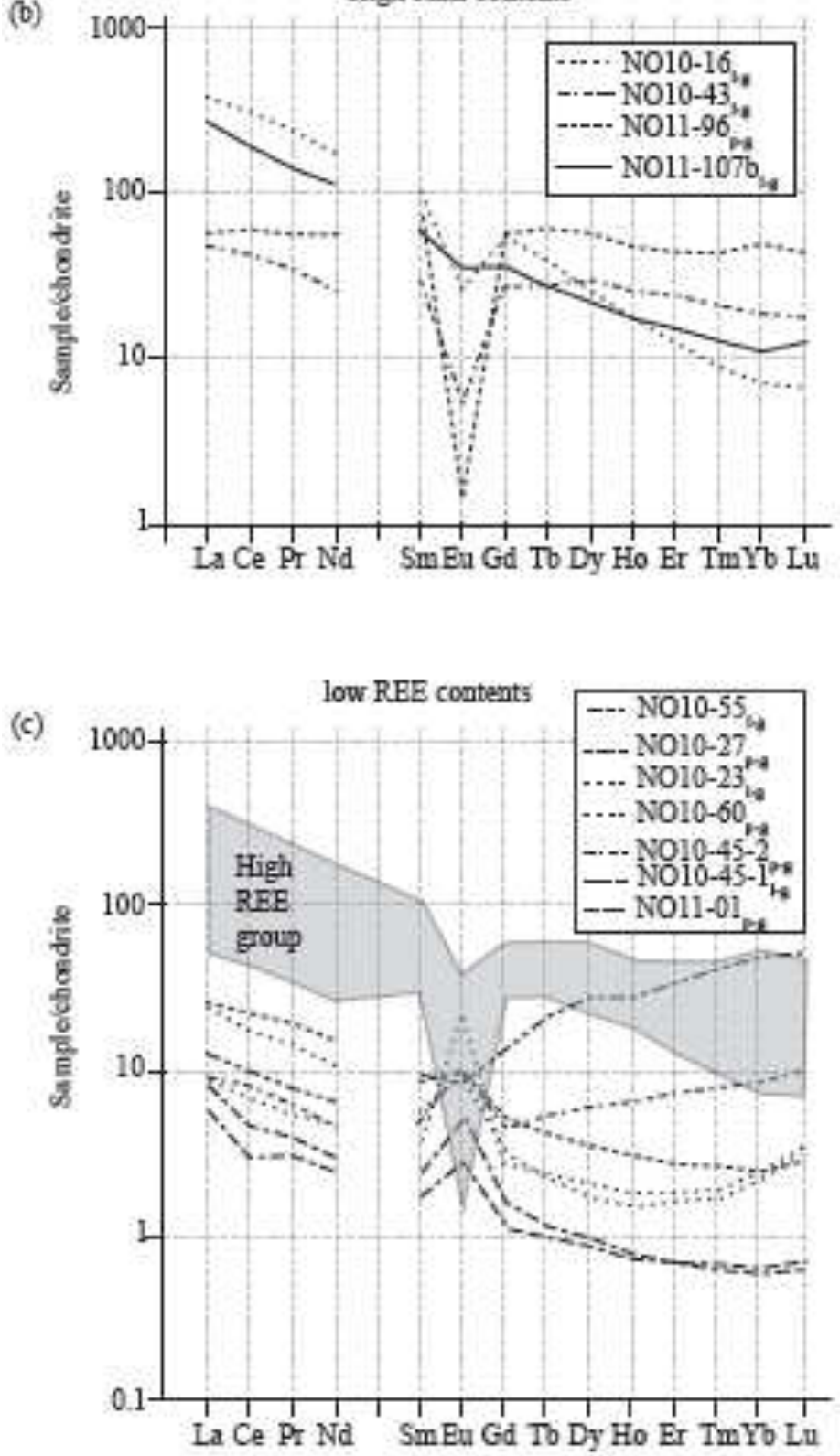

Fig. 14. REE patterns of (a) WGR gneisses, and (b) and (c) leucosomes and pegmatites normalized to chondrite (Sun \& MacDonough, 1989). See Table 1 for subscripts associated with names. 
(a)

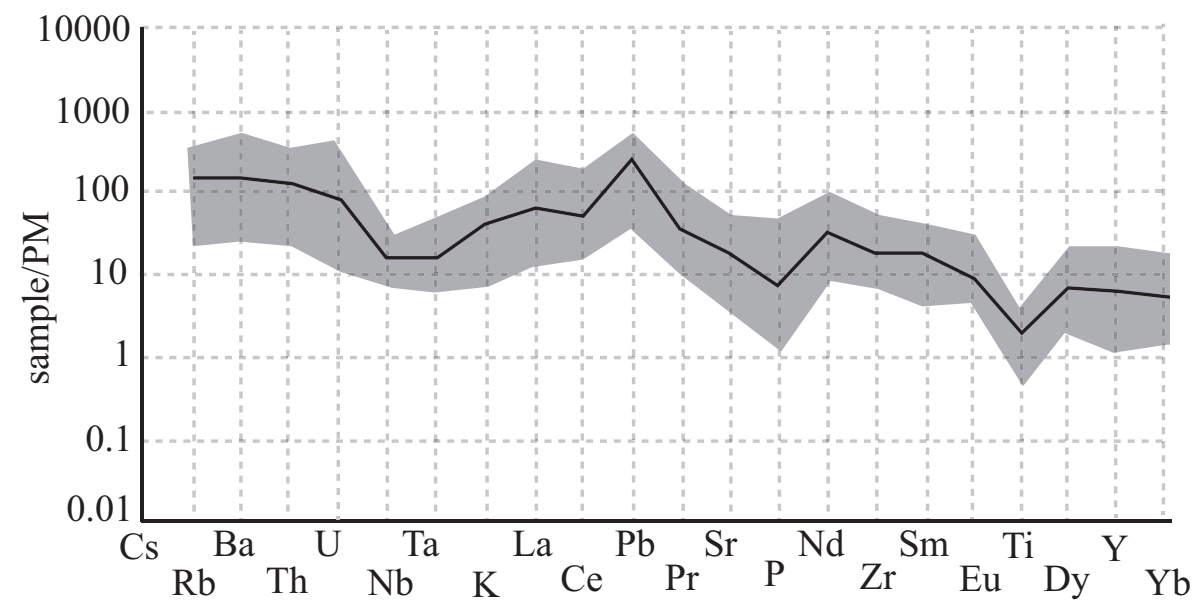

(b)

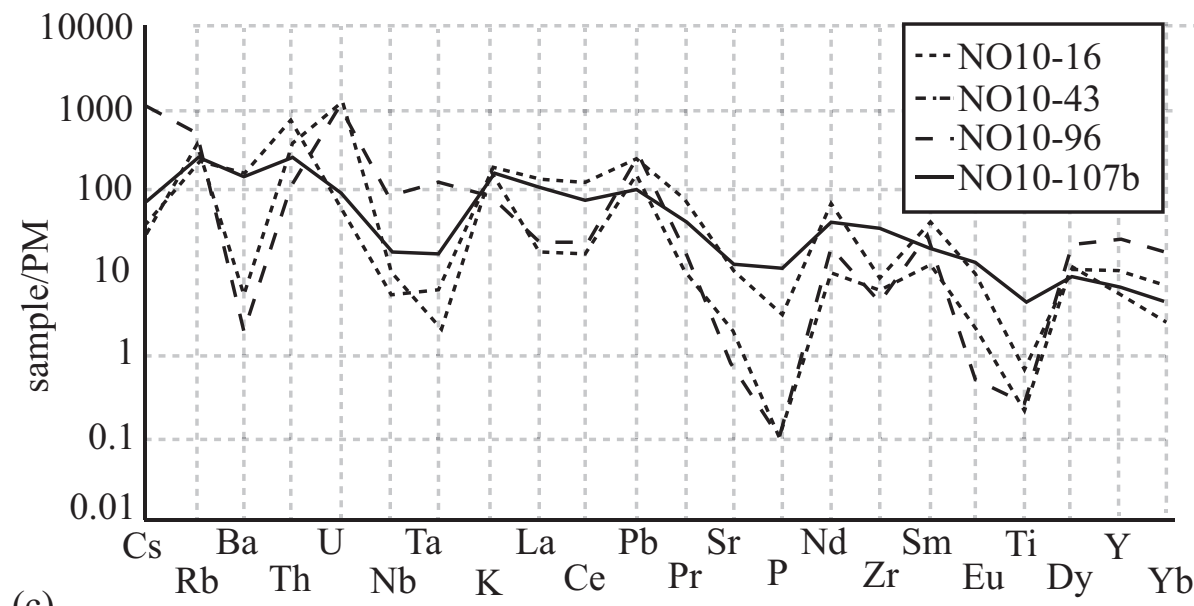

(c)

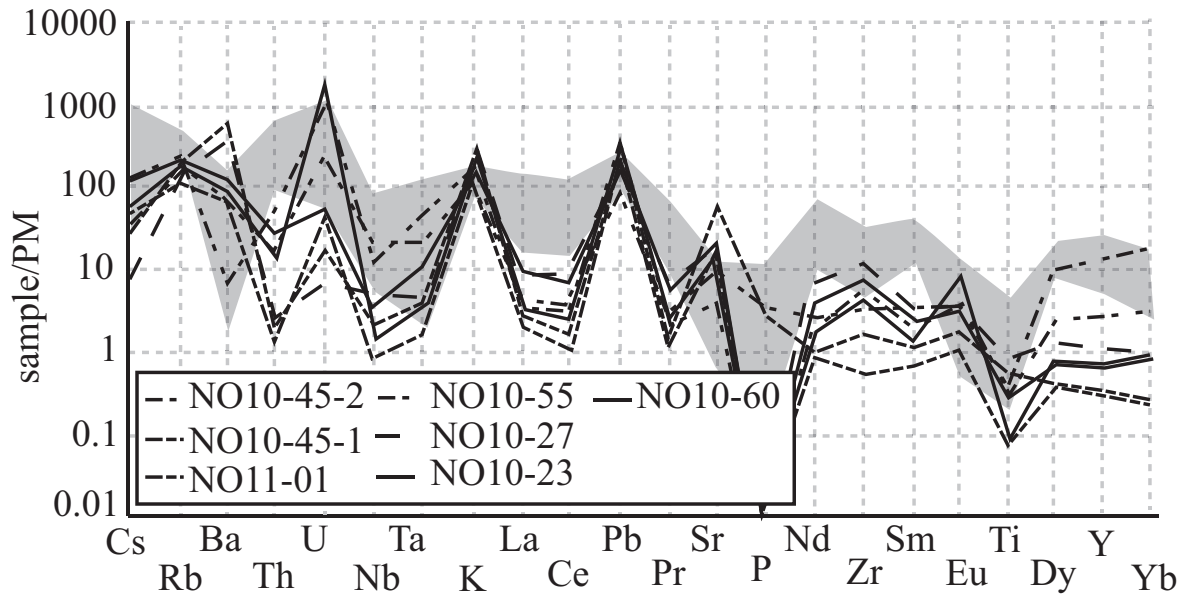

Fig. 15. Multi-element variation diagrams for (a) gneisses and (b) and (c) melt-derived lithologies hosted in gneisses. Shaded area in (c) corresponds to samples presented in (b). Normalized to primitive mantle (PM = primitive mantle; Sun \& MacDonough, 1989). 
(a) Flemsøy
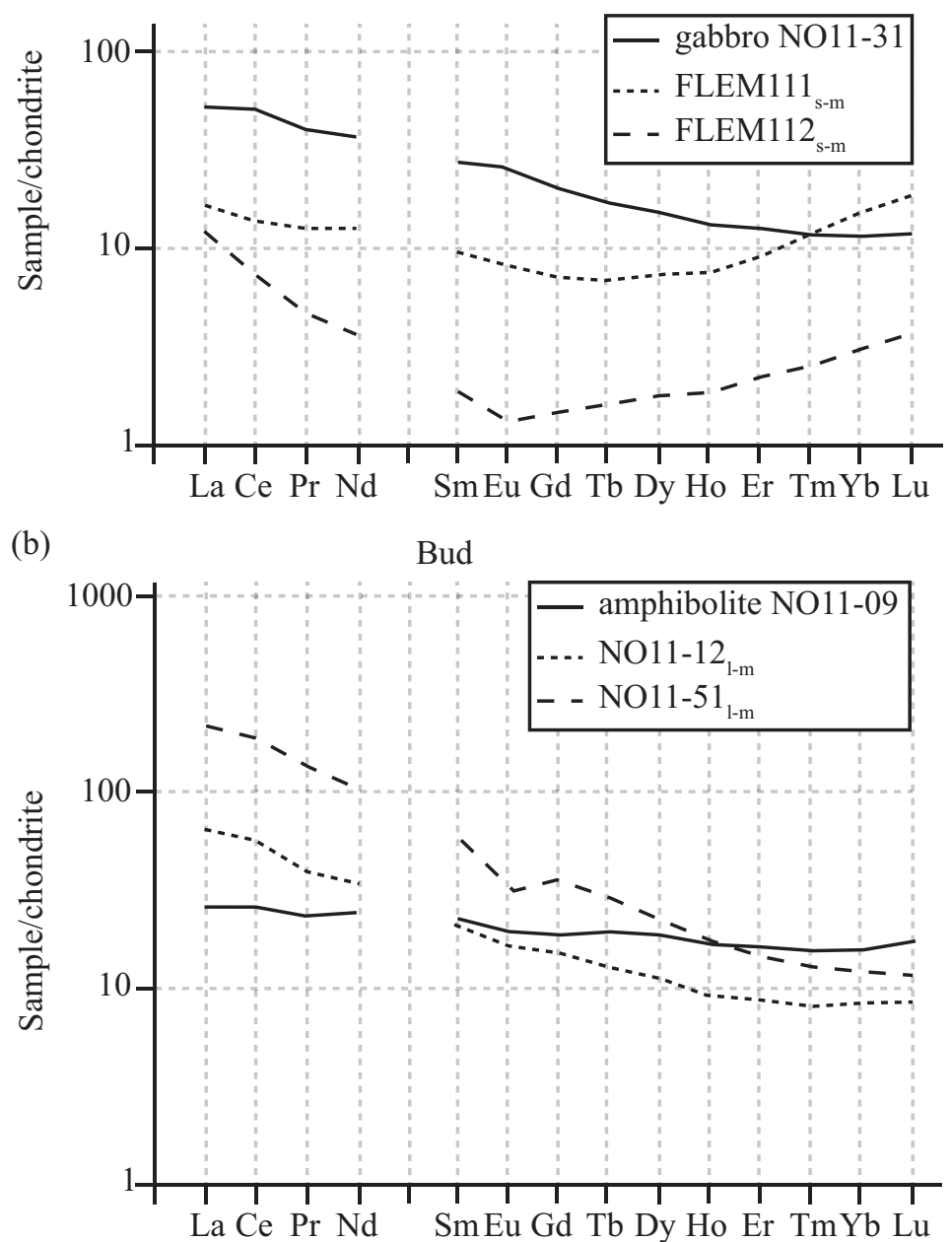

Fig. 16. REE patterns of (a) segregations in mafic rocks, Flemsøy, and (b) leucosomes from Bud compared to their respective hosts, all normalized to chondrite (Sun \& MacDonough, 1989). See Table 1 for subscripts associated with names. 

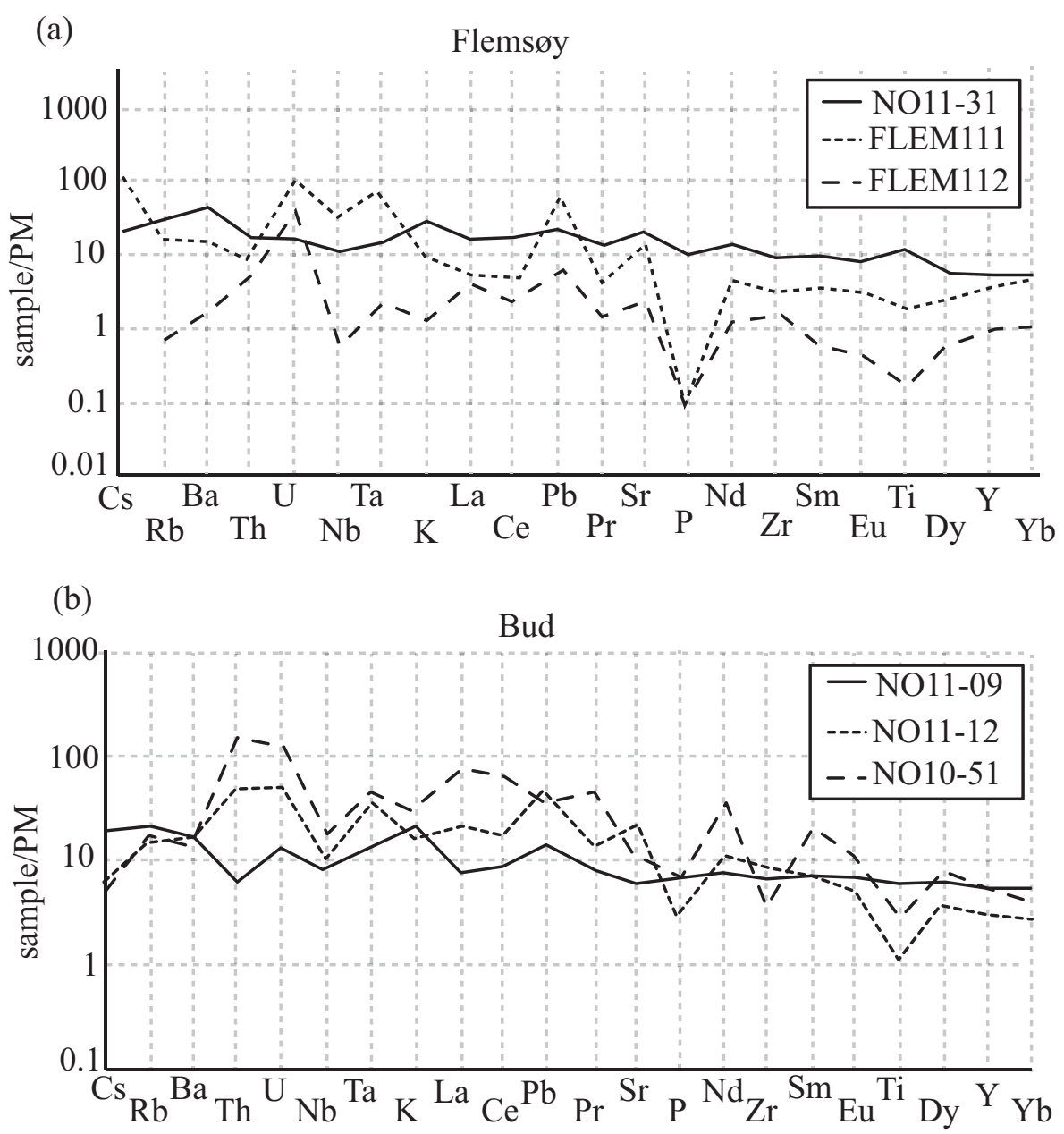

Fig. 17. Multi-element variation diagrams for samples and their mafic hosts from (a) Flemsøy and (b) Bud. Normalized to primitive mantle (PM = primitive mantle; Sun \& MacDonough, 1989). 

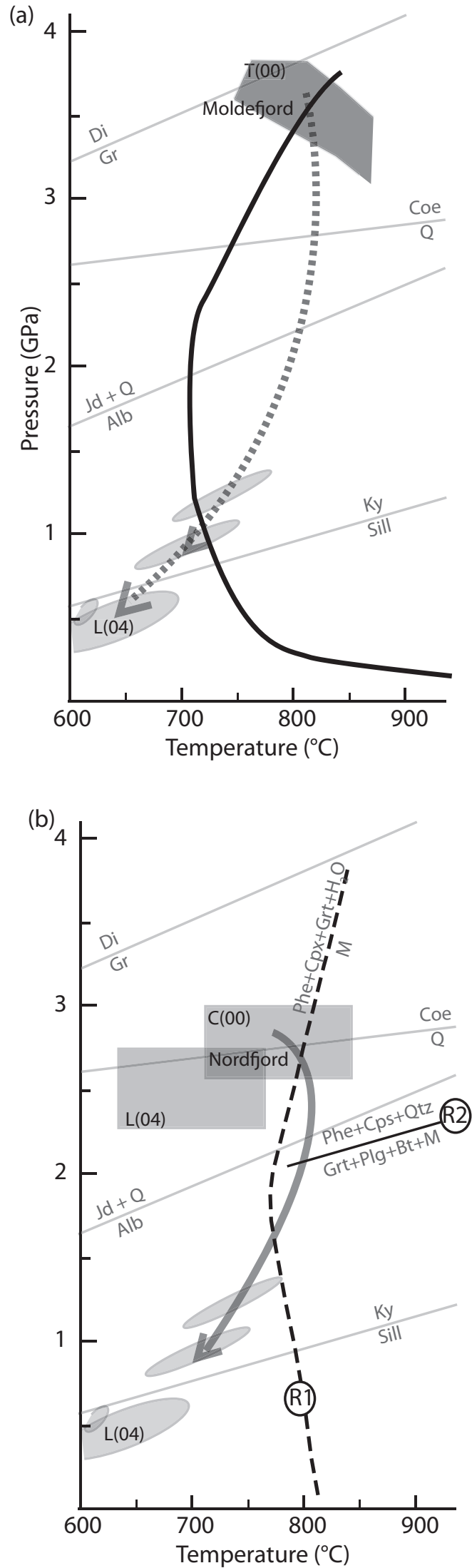

Fig. 18. (a) Comparison between $P-T$ paths for the UHP Moldefjord zone (dashed black line) with the hydrated basalt solidus (bold solid line, Kessel et al., 2005), and (b) for the UHP Nordfjord zone (bold grey line) and muscovite partial melting reactions $(\mathrm{R} 1)$ and (R2), from Auzanneau et al. (2006). L(04) = Labrousse et al., 2004, T(00) = Terry et al., 2000 and $\mathrm{C}(00)=$ Cuthbert et al., 2000. 
Metapelites
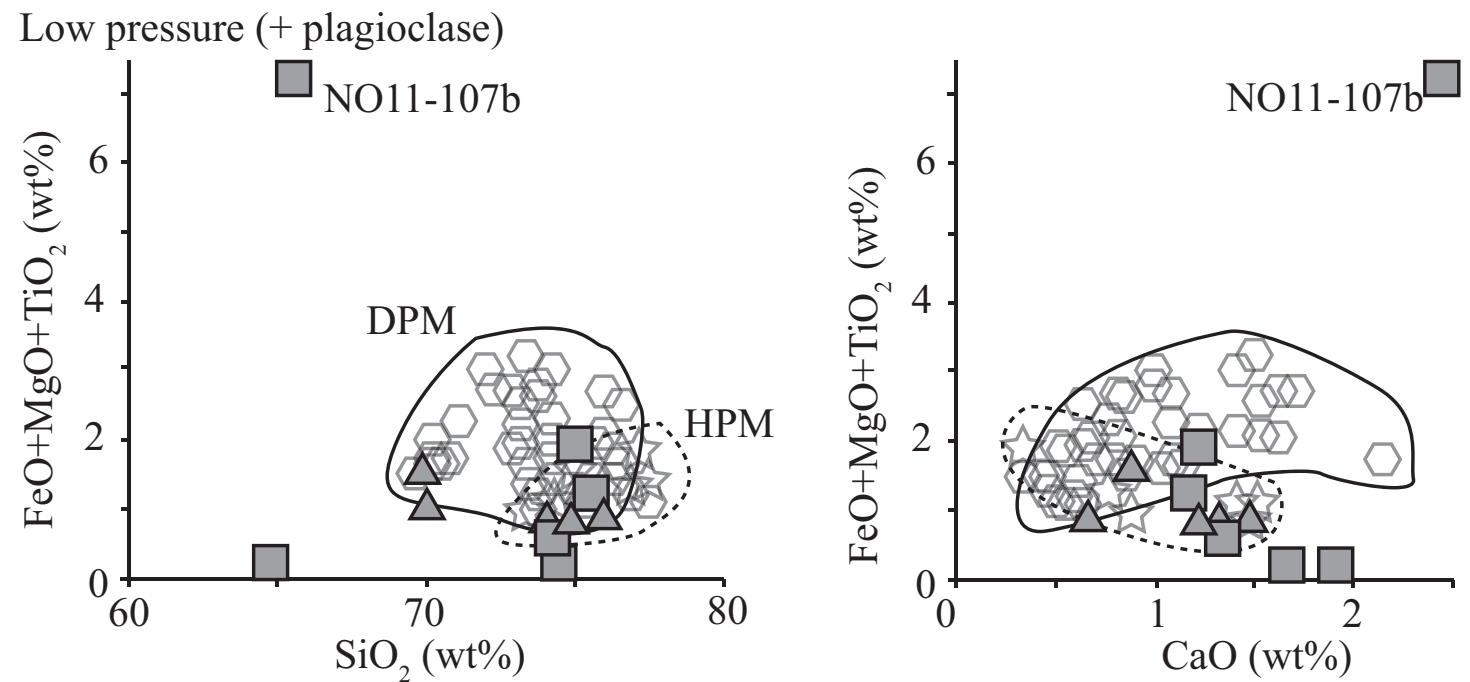

High pressure (without plagioclase)
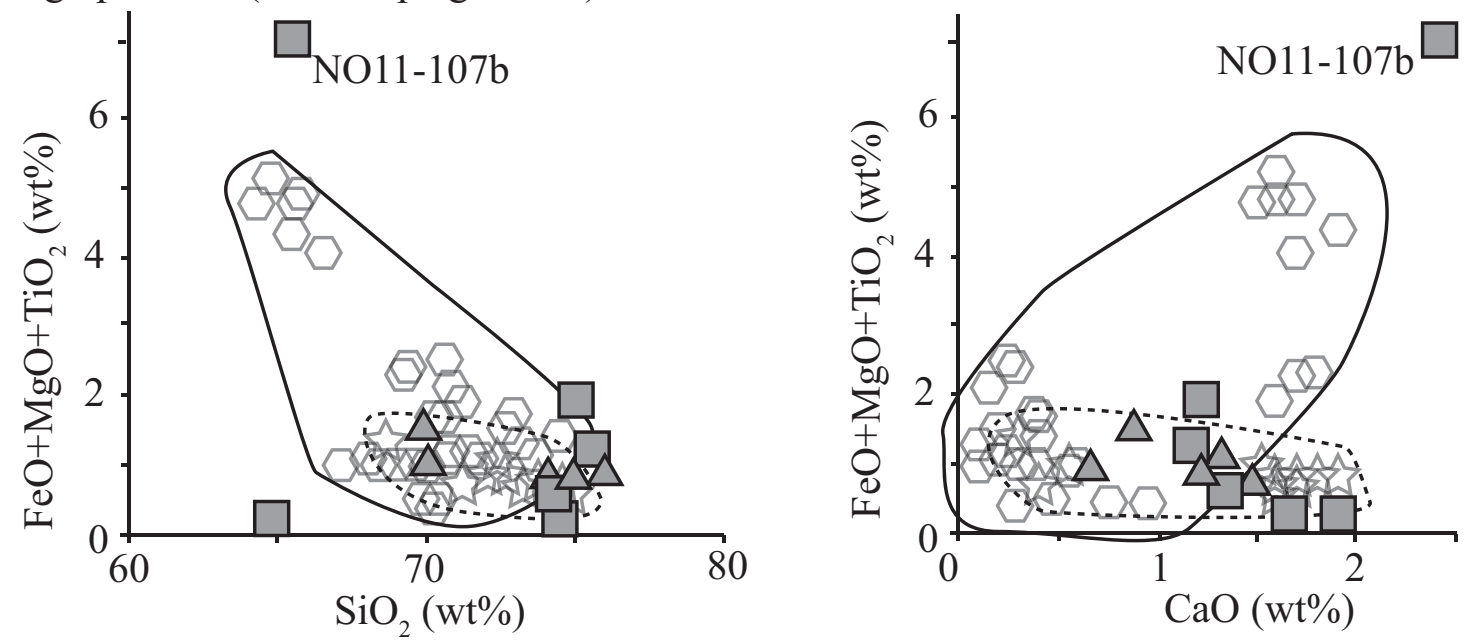

Natural lithologies

leucosomes

$\triangle$ pegmatites

Experimental glass

dehydration $\mathrm{H}_{2} \mathrm{O}$-present

(DPM) (HPM)

Fig. 19. Comparison between natural leucosome and pegmatite compositions from samples hosted in gneisses and experimental glass compositions (high pressure $=$ Hermann $\&$ Spandler (2008) and Patiño-Douce \& Johnston (1991); low pressure = Castro et al. (2008), Patiño-Douce \& Beard (1995) and Pickering \& Johnston (1998)). Bold line = dehydration melting experiments; dashed line $=\mathrm{H}_{2} \mathrm{O}$-present melting experiments. 
High pressure(without plagioclase)
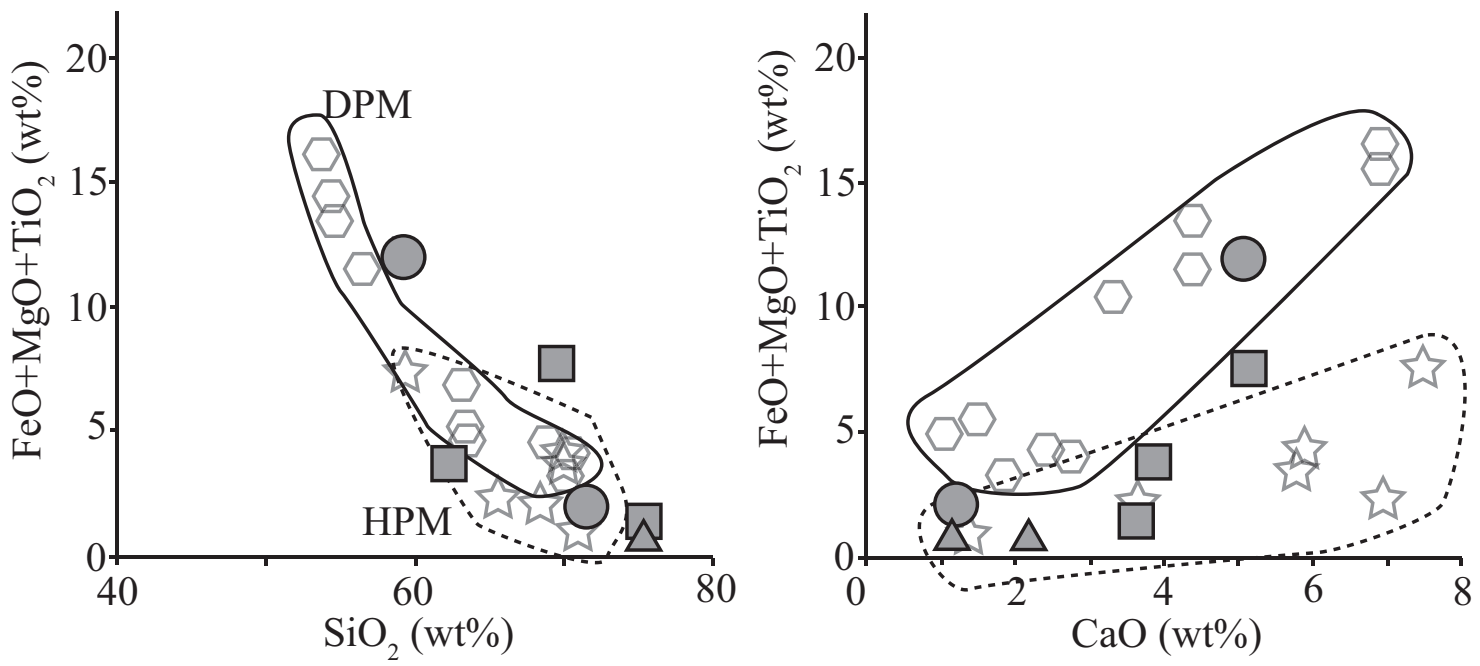

Natural lithologies

segregation

$\triangle$ pegmatite
Experimental glass

dehydration $\hat{\mathrm{H}_{2}} \mathrm{O}$-present (DHP) (HPM)

Fig. 20. Comparison between natural samples hosted in mafic rocks and experimental glass compositions (Rapp \& Watson, 1995; Prouteau et al., 2001). Bold line = dehydration melting experiments; dashed line $=\mathrm{H}_{2} \mathrm{O}$ present melting experiments.
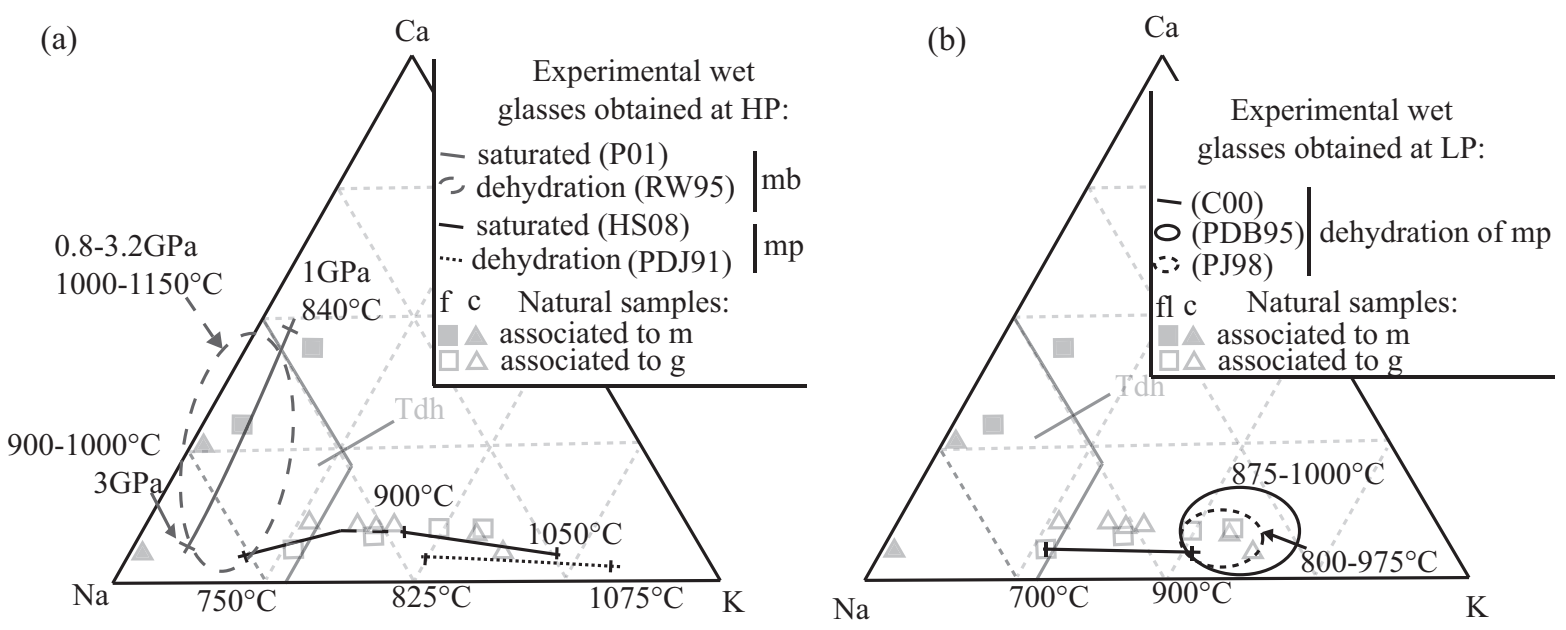

Fig. 21. Comparison between natural samples and (a) HP and (b) LP experimental glasses. (Na, Ca and K expressed in atom\%). (P01) = Prouteau et al. (2001); (RW98) = Rapp \& Watson (1995); (HS08) = Hermann \& Spandler (2008); (PDJ91) = Patiño-Douce \& Johnston (1991); (C08) = Castro et al. (2008) ; (PDB95) = Patiño-Douce \& Beard (1995); and, (PJ98) $=$ Pickering $\&$ Johnston (1998). Note that the symbols represent the natural samples classified in regard to their REE patterns, where: $\mathrm{f}=$ fractionated liquid; $\mathrm{c}=$ cumulate; $\mathrm{mp}=$ metapelite, $\mathrm{mb}=$ metabasite, $\mathrm{m}=$ mafic , and $\mathrm{g}=$ gneiss . 
TABLE 